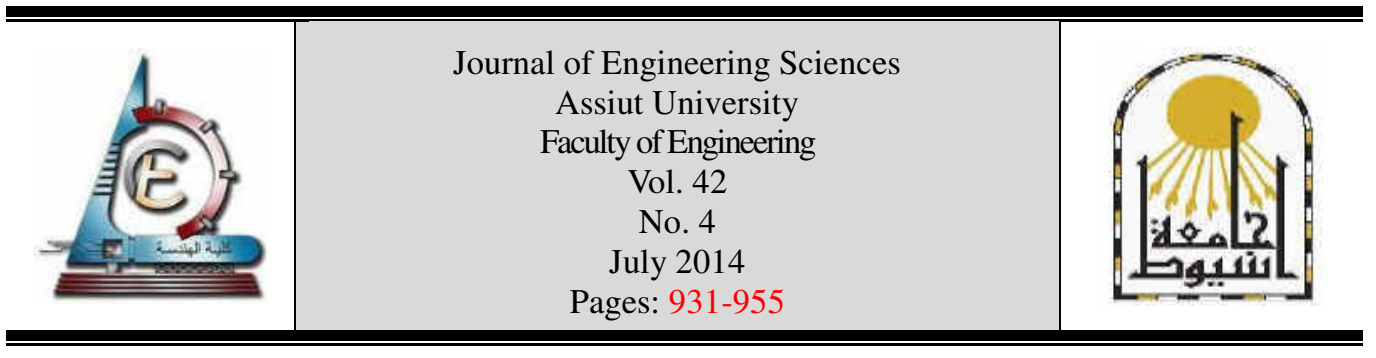

\title{
INVESTIGATION OF SOME POTENTIAL PARAMETERS AND ITS IMPACTS ON SALTWATER INTRUSION IN NILE DELTA AQUIFER
}

\author{
Ismail M. Abdelaty ${ }^{1,}$ *, Hany F. Abd-Elhamid ${ }^{2}$, \\ Maha R. Fahmy ${ }^{3}$ and Gamal M. Abdelaal ${ }^{4}$ \\ 1, 2, 3, 4 Staff in Department of Water and Water Structures Engineering, \\ Faculty of Engineering, Zagazig University, Zagazig 44519, Egypt
}

Received 18 May 2014; Revised 8 June 2014; accepted 18 June 2014

\begin{abstract}
Coastal aquifers represent an important source of freshwater in arid and semi-arid regions. The increased extraction from coastal aquifers decreases the freshwater spilled out to the sea. Consequently, seawater intrusion increases inland and wells become contaminated. Nile delta aquifer in Egypt is one of these aquifers which subject to sever seawater intrusion from Mediterranean Sea. Saltwater intrusion is considered one of the main processes that degrade waterquality by raising salinity. It may occur due to human activities and/or by natural events. Overpumping is considered the main cause of saltwater intrusion. Moreover, sea level rise accelerates saltwater intrusion. Due to climate change, it is expected a rise in temperature which would lead to an increase in the rates of evaporation and this will be accompanied by decrease in water level of the Nile, also this change would lead to sea level rise (SLR). A result to rise in population intensity and expected shortage in surface water would lead to an increase of extraction rate from groundwater. In this paper 3-D model (SEAWAT) is used to study seawater intrusion in Nile delta aquifer considering different scenarios, the first scenario is the increase of sea level by 25,50 and $100 \mathrm{~cm}$, the second is to decrease the surface water system by 25,50 and $100 \mathrm{~cm}$, the third is to increase the extraction rate by 25,50 and $100 \%$ and fourth scenario is a combination of while the three scenarios. The results show that saltwater intrusion in East Nile delta reach $76.25 \mathrm{~km}$ from shore line for base case, but reaches to $79.25 \mathrm{~km}, 79 \mathrm{~km}, 82 \mathrm{~km}$ and $83 \mathrm{~km}$ for Equiconcentration line 35 and reaches to $92.25 \mathrm{~km}, 92 \mathrm{~km}, 91.75 \mathrm{~km}$ and $92.75 \mathrm{~km}$ for scenarios1, 2, 3 and 4 respectively after 100 year for Equiconcentration line 1.00. It is also observed that salt water intrusion in the Middle reaches to $63.75 \mathrm{~km}$ from shore line for base case, but reaches to $67.75 \mathrm{~km}$, $67.25 \mathrm{~km}, 65.75 \mathrm{~km}$ and $67.50 \mathrm{~km}$ for Equiconcentration line 35 and reaches to $97 \mathrm{~km}, 97.50 \mathrm{~km}$, $107.75 \mathrm{~km}$ and $110 \mathrm{~km}$ for scenarios 1, 2, 3 and 4 respectively after 100 year for Equiconcentration line 1.00. It is clear that saltwater intrusion in the West reaches to $48.00 \mathrm{~km}$ from shore line for base case, but reaches to $49.00 \mathrm{~km}, 48.75 \mathrm{~km}, 45.50 \mathrm{~km}$ and $47.75 \mathrm{~km}$ for Equiconcentration line 35 and reaches to $73.75 \mathrm{~km}, 74 \mathrm{~km}, 79.50 \mathrm{~km}$ and $79.50 \mathrm{~km}$ for scenarios1, 2, 3 and 4 respectively after 100 year for Equiconcentration line 1.00. Finally increasing SLR or decreasing recharge from
\end{abstract}

Corresponding author.

Email address: Eng_abdelaty2006@yahoo.com 
Ismail M. Abdelaty et al., Investigation of some potential parameters and its impacts on ............

surface water or increasing extraction rate from wells increases saltwater intrusion in land direction but applying combination of these scenarios will damage large quantity of fresh water in the aquifer.

Keywords: Saltwater Intrusion, Climate Change, Sea Level Rise, Over-Pumping, SEAWAT, Nile Delta aquifer.

\section{Introduction}

Saltwater intrusion is a natural process that occurs in virtually all coastal aquifers connected to the sea as a consequence of the greater density of the seawater relative to the water in the aquifer, saltwater intrusion is a phenomenon with a long history of study as shown in Fig.1 [8].Saltwater intrusion has a direct impact on groundwater resources, soil salinity, agricultural productivity and quality in the coastal zone [11].

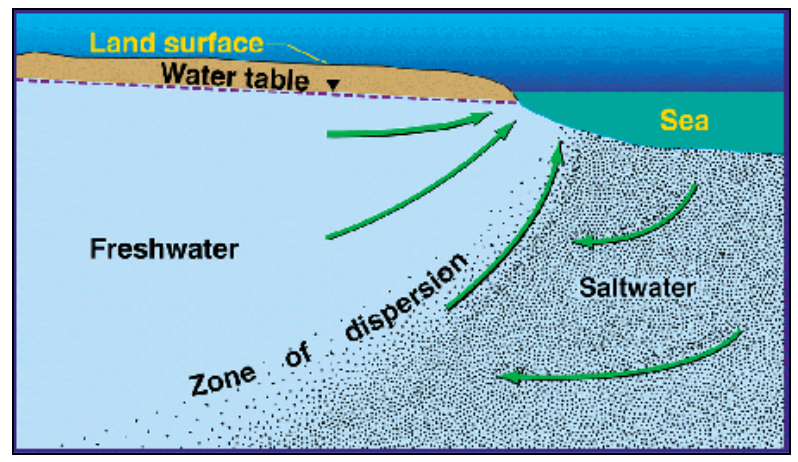

Fig. 1. Groundwater Flow Patterns and the Zone of Dispersion in Homogeneous Coastal Aquifer. Source:Water.Usgs.Gov/Ogw/Gwrp/Saltwater/Salt.htm

Saltwater intrusion or encroachment is shoreward movement of saltwater from ocean into coastal aquifers due to the over pumping of groundwater, and it is a dynamic equilibrium of groundwater movement, consequently leading to the possibility of polluting the groundwater and corroding subsurface structures [13]. When the groundwater is pumped from aquifers which are in hydraulic connection with the sea, the gradients that are set up may induce a flow of seawater from the sea toward the well [14]. The main causes of saltwater intrusion include over-abstraction of the aquifers, Seasonal changes in natural groundwater flow, Tidal effects, Barometric pressure, Seismic waves, Dispersion and Climate change - global warming and associated sea level rise . Different measures have been presented to control saltwater intrusion in coastal aquifers [6].The intrusion controlled by Physical model includes fresh water injection, saltwater extraction, and subsurface barrier. The fresh water injection rate of about $10 \%$ of the usage rate can effectively push the interface toward the shoreline, and keeping the pumping well free of salinity [38]. Presented various methods of preventing saltwater from contaminating groundwater sources including reduction of pumping rates, relocation of pumping wells use of subsurface barriers natural recharge artificial recharge abstraction of saline water combination techniques [37]. Coastal aquifers are affected by the rise in the sea level due to climate change and global warming. The rise in sea level will shift the saltwater interface further inland. As a result, the extraction wells that were originally in fresh groundwater may then be located in brackish water or saline water and upconing may occur [1]. Nile Delta aquifer is among the largest groundwater reservoirs in the world, due to the excessive pumping over the last few decades, the groundwater quality in the northern parts of the Delta has been deteriorated considerably, any additional pumping should be practiced in the middle Delta and pumping from the eastern and western parts 
should be reduced [33]. Abd-Elhamid and Javadi [2] developed a numerical model for simulating solute transport through saturated and unsaturated soils with the application to predict saltwater intrusion in coastal aquifers, the model includes coupling of transient water flow, air flow, heat transfer and solute transport, the model results showed that the developed of numerical model is capable of simulating saltwater intrusion into coastal aquifers with a good accuracy. Javadi et. al. [19] carried out a new methodology to control seawater intrusion in coastal aquifers using artificial surface recharge, this proposed method is based on a combination of abstraction of saline water near shoreline and recharge of aquifer using surface ponds, numerical model SUTRA is used to simulate this aquifer system in both $2 \mathrm{D}$ and $3 \mathrm{D}$ under steady state conditions, the model results show that the proposed system performs significantly better than using abstraction alone as it gives the least cost and least salinity in the aquifer. There are two type of interface first is sharp interface can solve by Analytical or numerical models and the second is diffuse interface can solve by numerical models.

Future sea-level rise is expected to occur at a rate greatly exceeding that of the recent past; the predicted increase in the sea level rise is in the range of $20-88 \mathrm{~cm}$ within the next 100 years. Numbers of studies have been carried out to estimate the future sea level changes based on past sea level changes due to thermal expansion, glaciers and ice caps and Greenland and Antarctic ice sheets melting. Fig .2 shows the estimated global average sea level rise from 1990 to 2100 [17].

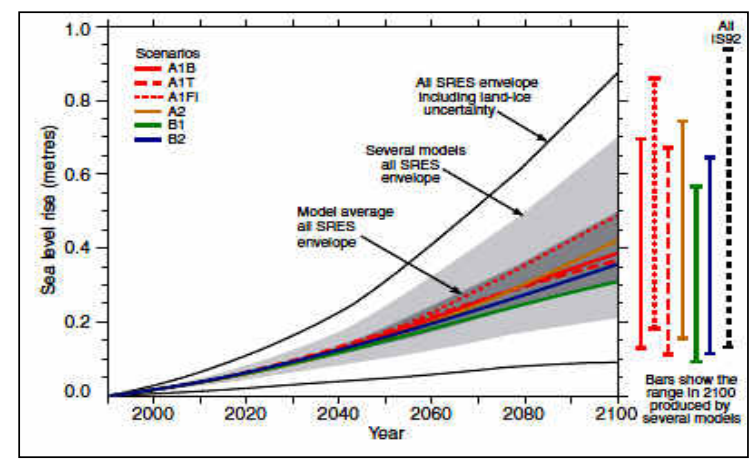

Fig. 2. SLR According to Global Climate of the $21^{\text {st }}$ Century (IPPC, 2001) [17].

The main transport processes of concern in groundwater include physical Transport Processes as advection, diffusion and dispersion, geochemical transport process as adsorption, biodegradation and chemical reactions. Advection describes the movement of groundwater under hydraulic or pressure gradient. The rate of advective transport is described by a modified version of Darcy's Law [9]. Molecular diffusion is the process describes the spread of particles through random motion from regions of higher concentration to regions of lower [4]. Dispersion is Spreading of pollutants due to heterogeneity of flow field (small scale dispersion, macro dispersion). There are two Kinds of Dispersion micro dispersion and macro dispersion (Small scale or large scale [26]. Mechanical dispersion is mixing caused by velocity variations around a mean flow velocity; it is expected to increase with increasing flow velocity. The groundwater models used to the simulation of groundwater flow and transport of pollutants in groundwater and can be classified as physical (e.g. a sand tank) or mathematical [5]. Mathematical models 
including analytical models and numerical models, like finite difference, finite element models [25]. Analytical equations that deal solely with the effects of changes in hydraulic head or gradient are gross simplifications of the real situation, and also cannot be expected to accurately predict the position of the saltwater interference. According to the GhybenHerzberg's Equation, the depth to the fresh water/sea water interface equals 40 times the freshwater hydraulic head or water level above sea level [24].

The available numerical models to estimate the variable density and concentration effects of the sea-water/fresh water groundwater interface (e.g. SHARP, SUTRA, HST3D and the SEAWAT program of MODFLOW) [24].Several numerical methods are available to solve the advection-dispersion equation for solute transport [23] such as Eulerian method, Lagrangian method Mixed Eulerian-Lagrangian method. SEAWAT is selected in this study to simulate saltwater intrusion in Nile delta one of the strong programs in simulate saltwater intrusion. A number of pervious researchers studied the effect of SLR and increasing extraction rate from groundwater in two-dimensional but the study of decreasing surface water changes due to climatic change in River Nile and combination of these scenarios did not study yet in threedimensional in Nile delta aquifer so this research aimed to study these scenarios.

\section{Study area}

Study area is Nile delta which located on Northern Egypt, The area is bounded by River Nile in South, Ismailia canal in East, Mediterranean Sea in North and Nubaria canal in West. It located between Latitudes $30^{\circ} 00^{\circ}$ and $31^{\circ} 45^{\circ} \mathrm{N}$, and longitudes $29^{\circ} 30^{\circ}$ and $32^{\circ}$ $30^{`}$ E. Its area of about $25,000 \mathrm{~km}^{2}$ with about $200 \mathrm{~km}$ from South to North, and the coastline is about $300 \mathrm{~km}$ long. [21].

\subsection{Geological properties}

Nile Delta is mostly occupied by the Tertiary and Quaternary deposits, Tertiary aquifers are including the Eocene, Oligocene, Miocene rocks and Pliocene Rocks. Quaternary aquifers cover the greater part of the Nile Delta and are particularly developed in the northern portion and are dominant in the Nile Delta. The sediments constitute variable proportions of sands, clays and gravels with lateral variation and variable thicknesses [30]. Quaternary aquifers are including Holocene deposits with maximum thickness of about 77 $\mathrm{m}$ and Pleistocene deposits composed of coarse-grained Quartizitic sands and gravels with discontinuous occasional clay lenses with an average thickness of $700 \mathrm{~m}$ [15].

\subsection{Hydraulic parameters of the Aquifer}

The Nile is completely controlled by the High Aswan Dam and a series of barrages along its course to the Mediterranean Sea. Water released from the dam is distributed among the whole country through a network of major and branch canals, lateral and distribution canals and field channels [21]. The Nile Delta Quaternary aquifer is considered as a semi-confined aquifer. It covers the whole Nile Delta. Its thickness varies from $200 \mathrm{~m}$ in the Southern parts to $1000 \mathrm{~m}$ in the Northern parts, [28]. Figure.3 shows the depth to the groundwater table in this aquifer ranges between 1-2 $\mathrm{m}$ in the North, $3-4 \mathrm{~m}$ in the Middle and $5 \mathrm{~m}$ in the South. Different estimated depths to groundwater table that have been reported by RIGW (2002) [29] and (Morsy, 2009) [22]. According to RIGW database the distribution of groundwater salinity as iso-salinity 1000 PPM comparison from period 1960, 1980, 1992 and 2008 as shown in Fig.4. 


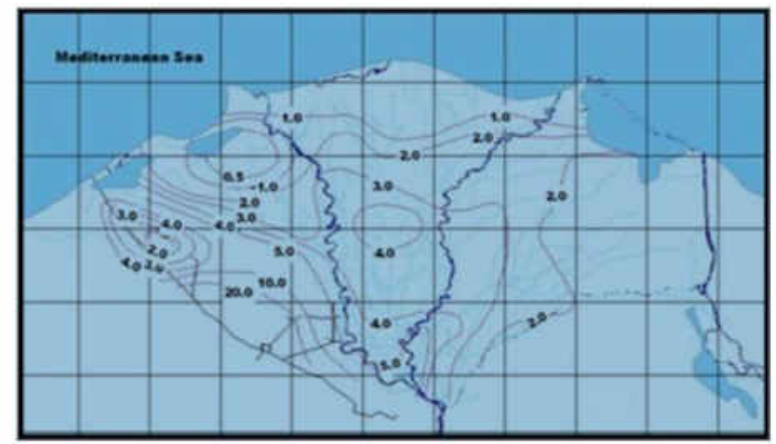

Fig. 3. Average Depth to Groundwater in the Quaternary Aquifer Recorded in 2002 (RIGW, 2002) [29].

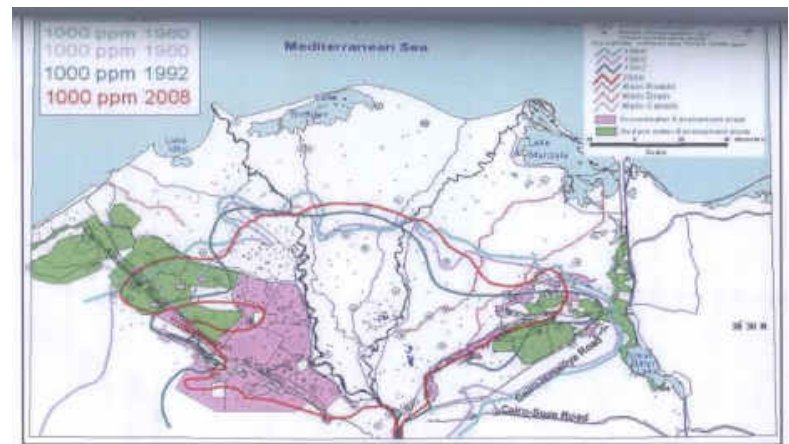

Fig. 4. Salinity (TDS) in GW during Period 1960, 1980, 1992 and 2008 (Morsy, 2009) [22]

The most important parameter for controlling flow characteristic is the hydraulic prosperities such vertical and horizontal hydraulic conductivity, Specific yield, storage coefficient, transmissivity and porosity as show in Table.1. Recharge by the downward leakage due to irrigation excess water and canals infiltration towards the aquifer ranges between 0.25 and 0.80 $\mathrm{mm} /$ day also recharge by rainfall to the study area aquifer takes place only during the winter months with average rainfall of $25 \mathrm{~mm} /$ year (RIGW, 1980) [27]. Abstraction well inventory for Nile delta region has been carried out by RIGW in 1992, 1995, 1997 and 2002 and new functionality is added to it in 2008. Values of extraction rate in Nile delta region for different governorate and for tow period 1992 reach $3.30 \mathrm{Mm}^{3} /$ year and $4.90 \mathrm{Mm}^{3} /$ year 2008 .

Table. 1.

Hydraulic Properties of Quaternary Aquifer in Nile Delta

\begin{tabular}{|c|c|c|c|c|c|c|}
\hline \multirow{3}{*}{ Main hydraulic units } & $\begin{array}{c}\text { Hyrollic } \\
\text { Conductivity }\end{array}$ & Transmissivity & $\begin{array}{c}\text { Storage } \\
\text { Cofficient }\end{array}$ & $\begin{array}{c}\text { Specific } \\
\text { yield }\end{array}$ & Prosity & $\begin{array}{c}\text { Effective } \\
\text { Prosity }\end{array}$ \\
\hline & $\mathbf{K}$ & $\mathbf{T}$ & $\mathbf{S}$ & Ss & n & $\mathbf{n}_{\text {eff }}$ \\
\hline & m/day & $\left(\mathrm{m}^{2} / \mathrm{day}\right)$ & (m/day) & $(1 / \mathrm{m})$ & $\%$ & $\%$ \\
\hline RIGW(1992)[28] & 75 & $15000-75000$ & $10^{-4}-10^{-3}$ & ........ & $25-40$ & ........ \\
\hline Farid(1980)[12] & 112 & $\ldots \ldots . .$. & $2.35 * 10^{-3}$ & ........ & 40 & 37.35 \\
\hline Zaghloul(1958)[39] & 119 & ......... & $10^{-4}-10^{-3}$ & 0.15 & 30 & \\
\hline Shahin(1981)[31] & 50 & $2500-25900$ & $10^{-5}-10^{-4}$ & 0.2 & 25 & 23.25 \\
\hline $\operatorname{Leaven}(1991)[20]$ & 150 & $10350-59800$ & ......... & ........ & $25-30$ & $\ldots \ldots \ldots$ \\
\hline Bahr(1995)[7] & 75 & ......... & $1.1 * 10^{-3}$ & ........ & 25 & 18 \\
\hline
\end{tabular}




\subsection{Meteorological aspects and climatic changes}

Egypt's climate is hot, dry, deserted and is getting warmer. During the winter season (December- February), Lower Egypt's climate is mild with some rain, primarily over the coastal areas, while Upper Egypt's climate is practically rainless with warm sunny days and cool nights. During the summer season (June- August), the climate is hot and dry all over Egypt. Summer temperatures are extremely high, reaching $38^{\circ} \mathrm{C}$ to $43^{\circ} \mathrm{C}$ with extremes of $49^{\circ} \mathrm{C}$ in the southern and western deserts. The northern areas on the Mediterranean coast are much cooler, with a maximum of about $32^{\circ} \mathrm{C}$ [21]. The climate system is a complex, interactive system consisting of the atmosphere, land surface, snow and ice, oceans and other bodies of water, and living things. There are three fundamental ways to change the radiation balance of the Earth as changing the incoming solar radiation, changing the fraction of solar and by altering the long wave radiation from Earth back towards space [16].The global warming due to increasing concentrations of greenhouse gases in the atmosphere is estimated at 0.13 degree per decade [18] and is expected to have a full range of temperature projection of 1.1 degree to 6.4 degree by the end of this century. This range of temperature rise is expected to lead to melting of polar caps and expansion of water in deep oceans with a corresponding increase of sea level.

The Nile Delta shoreline extends from Alexandria to the west to Port-Said to the east with total length of about $240 \mathrm{~km}$ and is typically a smooth wide coast. The Nile Delta region is presently subject to changes, including shoreline changes, due to erosion and accretion, subsidence and sea level rise due to climate changes [3]. the Nile Delta coastal zone is highly vulnerable to the impacts of sea level rise through direct inundation and salt water intrusion.

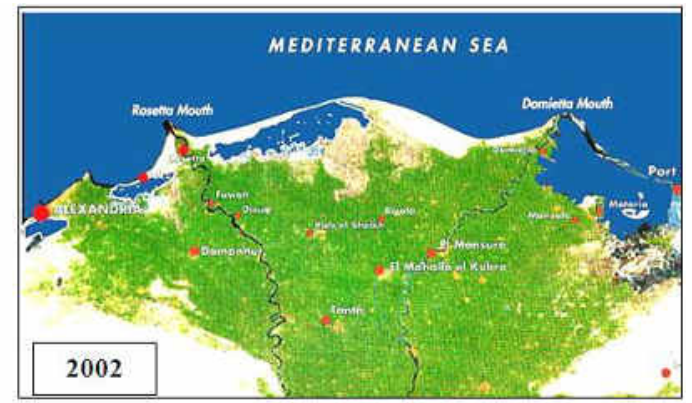

(a)

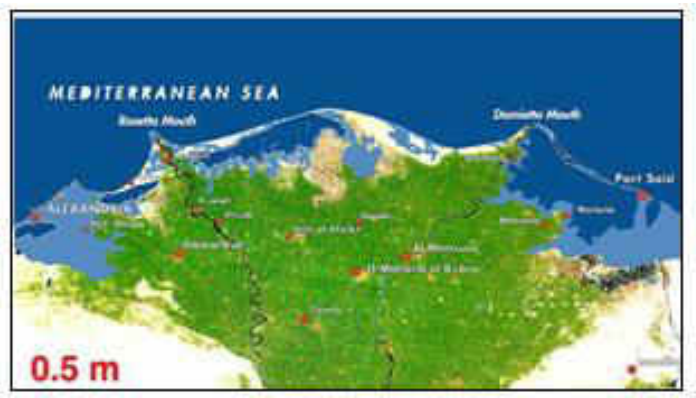

(b)

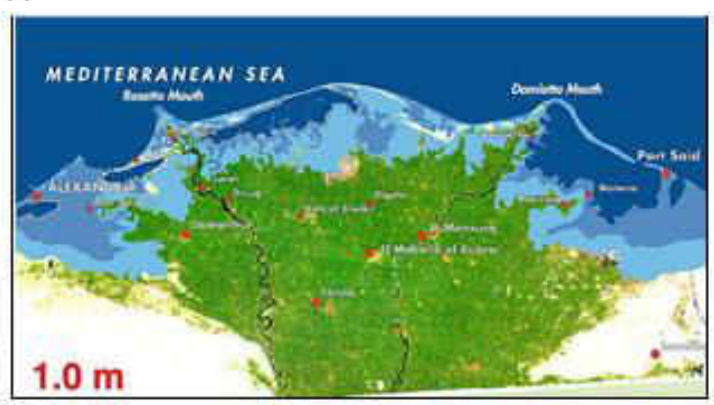

(c)

Fig. 5. (a, b, c) Satellite Maps of Nile Delta, Showing the Potential Impact of SLR with a- the Occurring Status in 2002 and the Coastal Inundation with a 0.5 and $1 \mathrm{~m}$ SLR[35]. 


\section{Numerical model}

SEAWAT-2000 is the latest release of SEAWAT computer program for simulation of three-dimensional, variable-density, transient ground-water flow in porous media. SEAWAT-2000 was designed by combining a modified version of MODFLOW-2000 and MT3DMS into a single computer program. SEAWAT-2000 contains all of the processes distributed with MODFLOW-2000 and also includes the Variable-Density Flow Process (as an alternative to the constant-density Ground-Water Flow Process) and the Integrated MT3DMS Transport Process [36]. The partial-differential equation of solute transport of contaminant in ground-water flow used in SEAWAT is [40]:

$$
\frac{\partial C}{\partial t}=\frac{\partial}{\partial X i}\left(D_{i j} \frac{\partial C}{\partial X_{i}}\right)+\frac{\partial}{\partial X_{i}}\left(V_{i} * C\right)+\frac{q_{S}}{\theta} * C_{S}+\sum_{k=1}^{k=n} R_{k}
$$

Where $\mathrm{C}$ is concentration of contaminant dissolved in ground water, $\mathrm{ML}^{-3}, \mathrm{t}$ is time (T), $\mathrm{X}$ is the distance along the respective Cartesian coordinate axis $(\mathrm{L}), \mathrm{D}_{\mathrm{ij}}$ is the hydrodynamic dispersion coefficient $\left(\mathrm{L}^{2} \mathrm{~T}^{-1}\right), \mathrm{V}$ is the seepage of linear pore water velocity $\mathrm{L} \mathrm{T}^{-1}, \mathrm{q}_{\mathrm{s}}$ is the volumetric flux of water per unit volume of aquifer representing sources (positive) and sink (negative), Cs is concentration of sources or sink, $\mathrm{ML}^{-3}, \Theta$ is the porosity of porous media, dimension less and $\mathrm{R}_{\mathrm{k}}$ is a chemical reaction term $\left(\mathrm{ML}^{-3} \mathrm{~T}^{-1}\right)$.

\subsection{Model geometry and boundary conditions}

Numerical model applied using SEAWAT-2000 software by using 194 rows and 260 columns for active and inactive cell with cell dimension $1.00 \mathrm{~km} * 1.00 \mathrm{~km}$ with variation depth for $200 \mathrm{~m}$ in South to $1000 \mathrm{~m}$ at shore line of sea. The model divided to eleven layers, the first represent clay layer as semi confined layer with average thickness $50 \mathrm{~m}$, other layer represent a quaternary aquifer with average depth $100 \mathrm{~m}$ as shown in Fig.6-a. Elevation of ground surface varies from 18.00 at South to zero level at North above MSL as shown in Fig.6-b; the thickness of aquifer varies between $200 \mathrm{~m}$ in South to $1000 \mathrm{~m}$ in North. Figure.7-a shows the vertical cross section in $\mathrm{x}$ direction from East to West and Fig.7-b shows the vertical cross section in y direction from North to South in Nile delta aquifer.

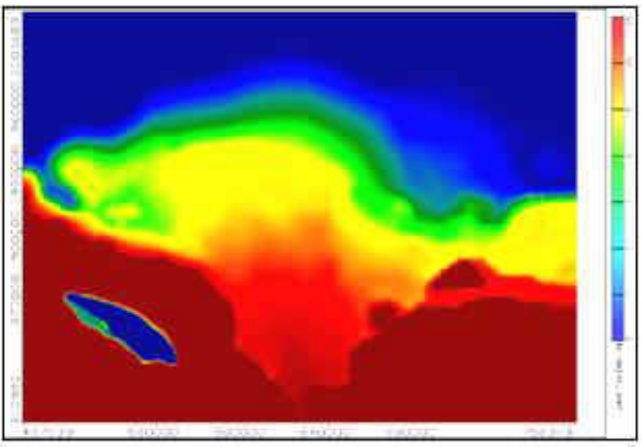

(a)

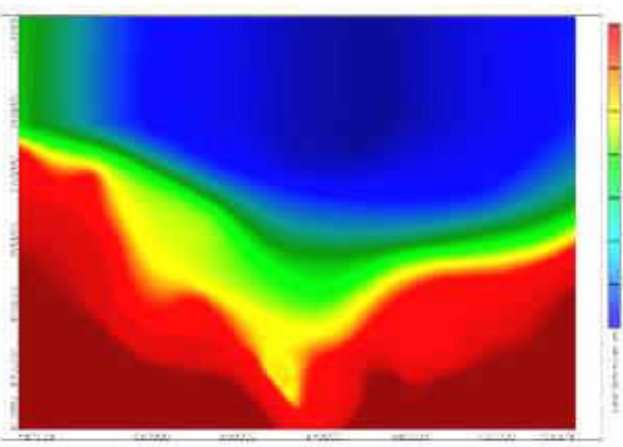

(b)

Fig. 6. Contour Maps for (a) Topographic and (b) Aquifer base surface 
Ismail M. Abdelaty et al., Investigation of some potential parameters and its impacts on............

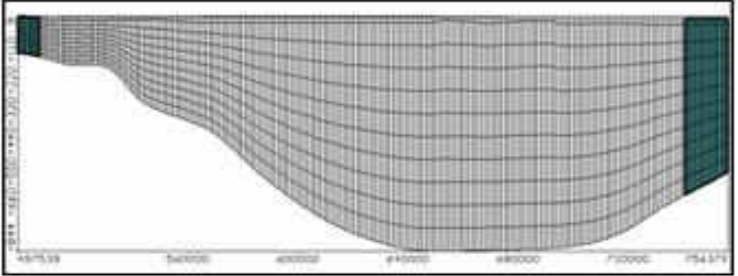

a)

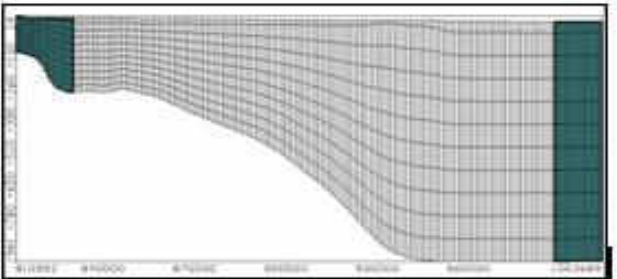

(b)

Fig. 7. Vertical Section in (a) $\mathrm{X}$ direction from East to West and (b) $\mathrm{Y}$ direction from North to South

The model bounded by constant head as $16.96 \mathrm{~m}$ above mean sea level at South and by constant head as zero value along shore line at North. South East bounded by Ismailia canal as water level in field start by $16.17 \mathrm{~m}$ from South to $7.01 \mathrm{~m}$ at East. South West bounded by El Rayah El Behery and Nubaria canal as water level in field start by $16.00 \mathrm{~m}$ from South to $0.50 \mathrm{~m}$ North above mean sea level and East boundary leave as free as shown in Fig.8-a. A concentration of $35000 \mathrm{mg} / \mathrm{l}$ (seawater TDS) is applied along the coastal zone where an inland flow from the sea occurs, the initial concentration of the groundwater was set to $0 \mathrm{mg} / \mathrm{l}$ as shown in Fig.8-b [34].
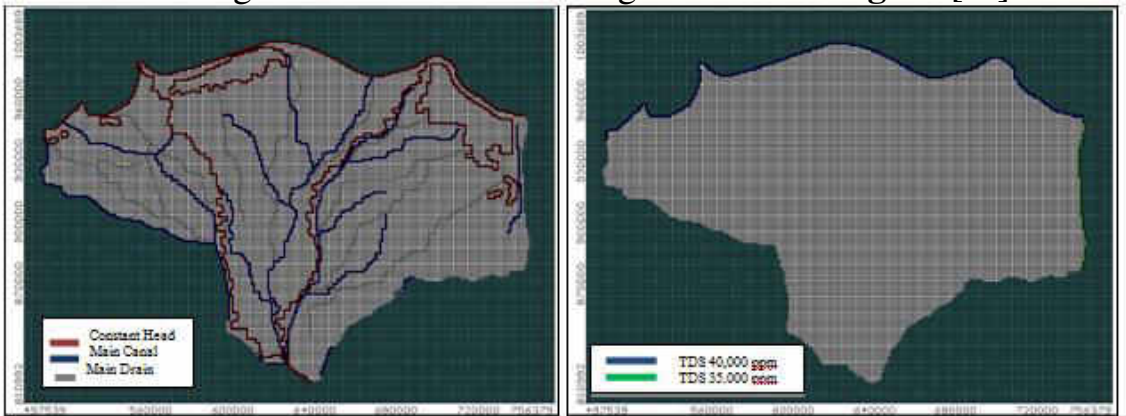

Fig. 8. Model Boundary Condition for (a) Head (b) Concentration

\subsection{Model hydraulic parameters}

Hydraulic parameters for each layer in model as hydraulic conductivity $(\mathrm{K})$, specific storage $\left(\mathrm{S}_{\mathrm{s}}\right)$, specific yield $\left(\mathrm{S}_{\mathrm{y}}\right)$ and total porosity are shown in Table.2. Recharge depend on the excess water from irrigation process and water seepage from canal plus and rainfall value this values was conducted by (RIGW, 1980) [27] as shown in Fig.9 location map of wells distribution as shown in Fig.10 based on the data collected by (RIGW) with total abstraction equal $2.78 * 10^{9} \mathrm{~m}^{3} /$ year in 2008 . The values of scale dependent as Longitudinal dispersivity $\left(\alpha_{\mathrm{L}}\right)$ equal $100 \mathrm{~m}$, Lateral dispersivity $\left(\alpha_{\mathrm{T}}\right)$ equal $10 \mathrm{~m}$, vertical $\left(\alpha_{\mathrm{V}}\right)$ dispersivity equal 1.00 and the value of diffusion coefficient equal $10^{-4} \mathrm{~m}^{2} /$ day [32].

Table 2.

Values of Hydraulic Properties in Nile Delta (El Arabi, 2007) [10].

\begin{tabular}{|c|c|c|c|c|c|c|}
\hline \multirow{3}{*}{$\begin{array}{c}\text { Main Hydraulic } \\
\text { Units }\end{array}$} & \multirow{3}{*}{ Layer No } & $\begin{array}{c}\text { Hydraulic } \\
\text { Conductivity }\end{array}$ & $\begin{array}{c}\text { Hyrollic } \\
\text { Conductivity } \\
\end{array}$ & $\begin{array}{c}\text { Storage } \\
\text { Cofficient }\end{array}$ & $\begin{array}{c}\text { Specific } \\
\text { Yield }\end{array}$ & $\begin{array}{c}\text { Effective } \\
\text { Prosity }\end{array}$ \\
\hline & & $\mathbf{K}_{\mathbf{h}}$ & $\mathbf{K}_{\mathbf{v}}$ & $\mathbf{S}$ & Ss & n \\
\hline & & m/day & $\left(\mathrm{m}^{2} /\right.$ day $)$ & $(\mathrm{m} / \mathrm{day})$ & $(1 / \mathrm{m})$ & $\%$ \\
\hline Clay & 1 & $0.10 \quad--0.25$ & $0.01 \quad--0.025$ & $10^{-3}$ & 0.10 & $50-60$ \\
\hline $\begin{array}{l}\text { Fins Sand with } \\
\text { LenSesof Clay }\end{array}$ & $2,3,4$ and 5 & 5 --- 20 & $0.5 \quad--2$ & $5 * 10^{-3}$ & 0.15 & 30 \\
\hline $\begin{array}{l}\text { Course Sand } \\
\text { Quaternary }\end{array}$ & $6,7,8$ and 9 & $20--75$ & $2---7.50$ & $2.50 * 10^{-3}$ & 0.18 & 25 \\
\hline $\begin{array}{c}\text { Graded Sand and } \\
\text { Gravel }\end{array}$ & 10 and 11 & 75 --- 100 & $7.50 \quad--10$ & $5 * 10^{-4}$ & 0.20 & 20 \\
\hline
\end{tabular}




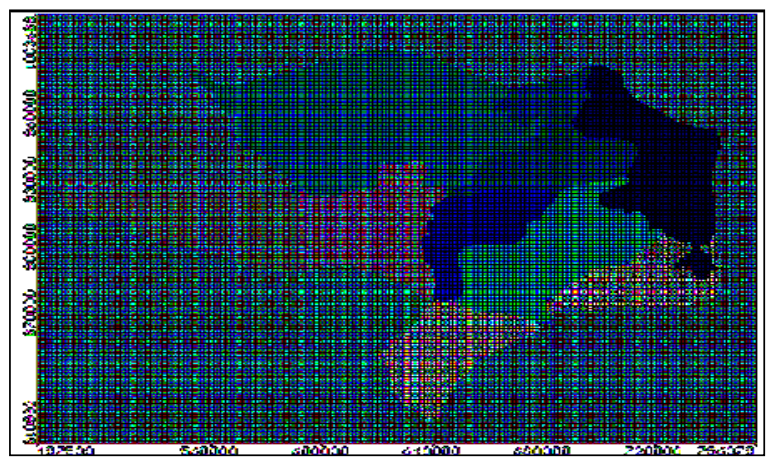

Fig.9. Distribution Map of Recharge

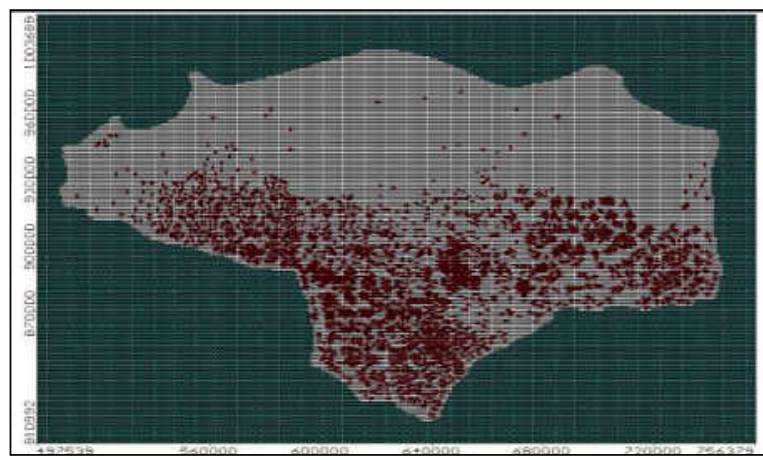

Fig. 10. Location Map of Extraction Wells

\section{Model output and calibration}

Distributions of Saltwater intrusion in Nile delta aquifer are the main output of transport model based on available data in 2008 compared with the values as shown in Fig.4. Figure 11-a shows distribution of TDS at layer 3 with average thickness $225 \mathrm{~m}$ in North and $50 \mathrm{~m}$ at south, at layer 6 with average thickness $450 \mathrm{~m}$ in North and $100 \mathrm{~m}$ at south as shown in Fig.11-b, at layer 9 with average thickness $675 \mathrm{~m}$ at North and $150 \mathrm{~m}$ at south as shown in Fig.11-c and bottom of Aquifer with average depth $900 \mathrm{~m}$ in North (at sea) and $200 \mathrm{~m}$ at south as shown in Fig.11-d.

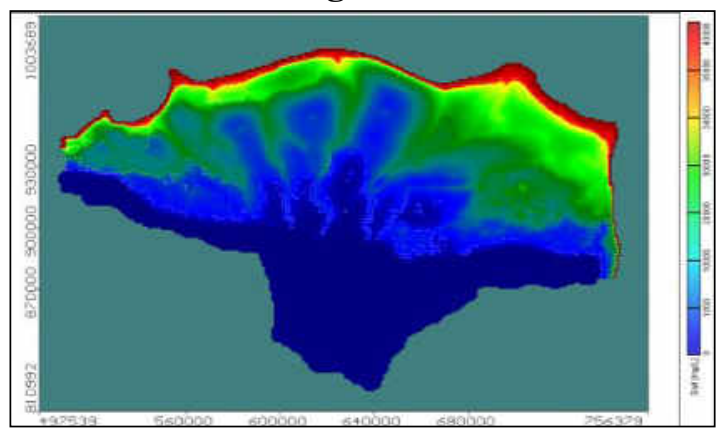

(a)

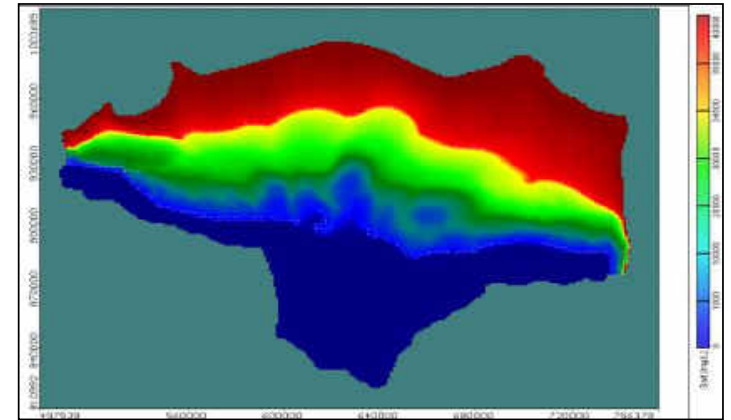

(b) 


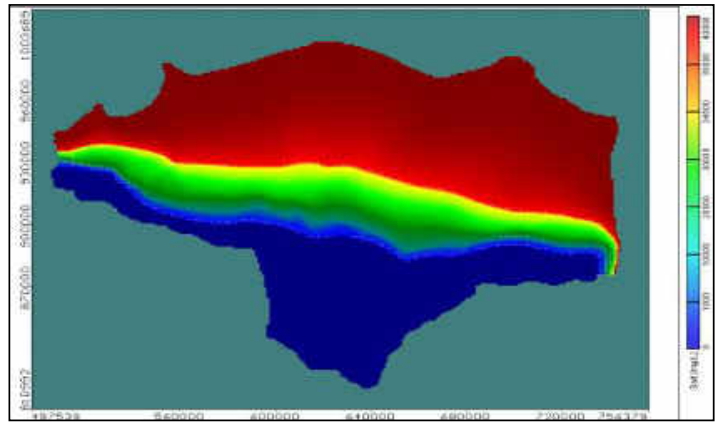

(c)

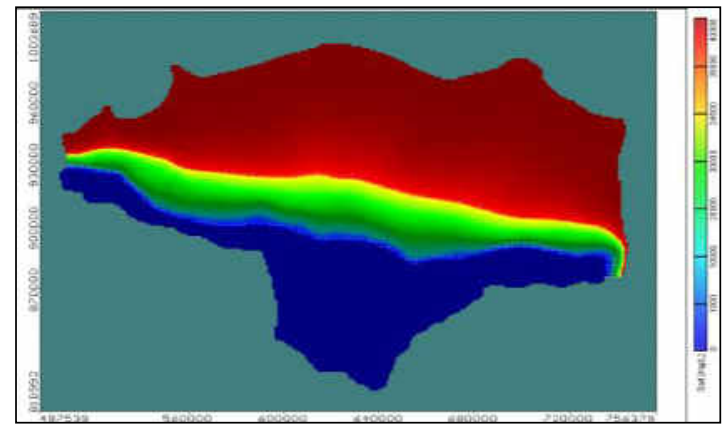

(d)

Fig. 11. Areal Distribution of TDS in Nile Delta Aquifer at (a) Layer 3, (b) Layer 6, (c) Layer 9 and (d) Layer 11

Calibration is a process that show the difference between calculated salt concentration from model and salt concentration in observation well at field based on available data from (RIGW) at 2008 as shown in Fig.4. Number of transport model such as SEAWAT need period of time to reach steady state, this period depend on software type as $2 \mathrm{D}$ or $3 \mathrm{D}$ and aquifer geometry such as area or depth, when the concentration keep to constant with time at this time the model reach to steady state. This model took about 730000 day to reach steady state condition. After this time the different scenarios applied to the model. On the other hand, Fig.12- a shows the mass balance of salts entering and leaving the system through all sources and all sinks at start of simulation, it is also the total mass of salts remain in the system at the end of each stress period and salt balance take place when the input salt equal output salt as shown in Fig.12-b.

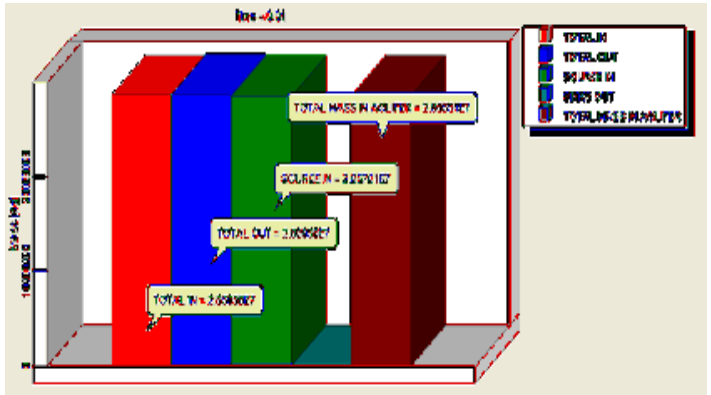

(a)

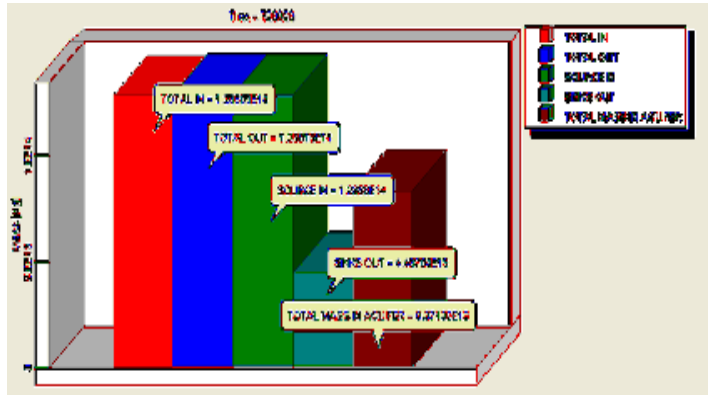

(b)

Fig. 12. Salt Balance Components at (a) Initial time and (b) End time

\section{Results and Discussions}

The model run and calibrated under available data in 2008 this case consider base case, the values of head and concentration as mentioned before which considered the base case. Three typical cross section applied in Nile delta, the first (Sec I) in West delta, Second in (Sec II) Middle delta, third (Sec III) in East Nile delta as shown in Fig.13. 


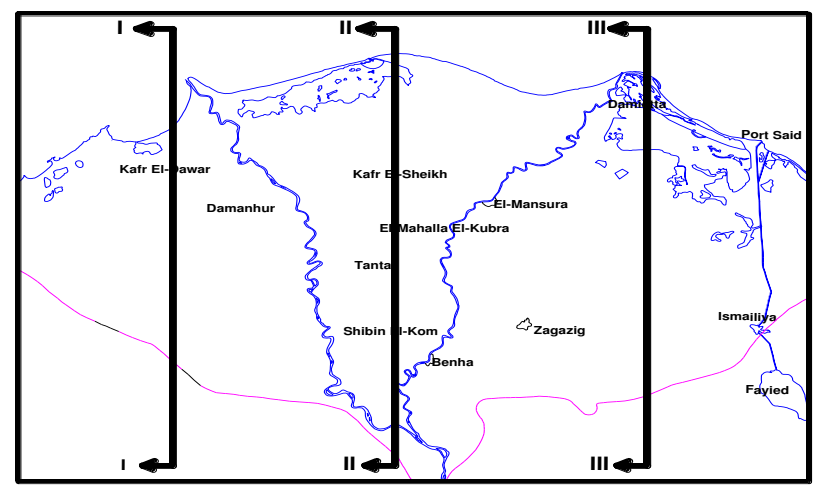

Fig. 13. Typical Cross Section in Nile Delta Aquifer

\subsection{Base Case}

Distribution of saltwater intrusion as TDS in Nile delta aquifer Equiconcentration line 35 and 1 is shown in Fig.11. According to Sec $\mathbf{I}$ in the West the line 35.0 moved inland by a distance of $48.00 \mathrm{~km}$ from shore line and Equi-line 1 moved inland by a distance of 72.50 $\mathrm{km}$ from shore line so the transition zone equal $24.50 \mathrm{~km}$ as shown in Fig.14-a. It is also clear that at Sec II in the Middle the Equi-line 35 moved inland by a distance of $63.75 \mathrm{~km}$ from shore line and Equi-line 1 moved inland by a distance of $93.75 \mathrm{~km}$ from shore line so the transition zone equal $30.00 \mathrm{~km}$ as shown in Fig.14-b. It is also observed that at Sec III in the East the Equi-line 35 moved inland by a distance of $76.25 \mathrm{~km}$ from shore line and Equi-line 1 moved inland by a distance of $90.75 \mathrm{~km}$ from shore line so the transition zone equals to $14.50 \mathrm{~km}$ as shown in Fig.14-c.
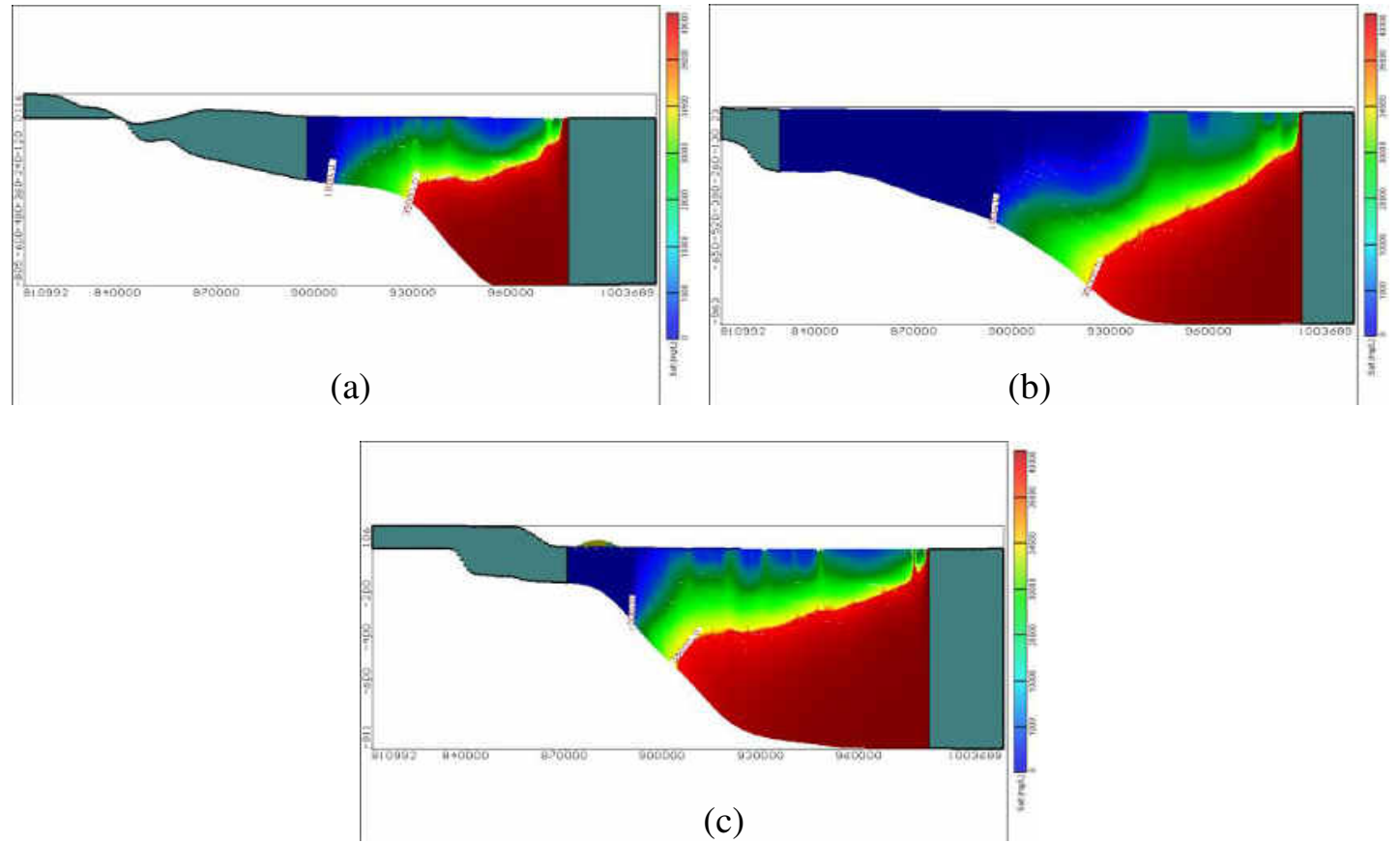

Fig. 14. Areal Distribution of TDS in Nile delta Aquifer for Base Case at (a) Sec I (b) Sec II and (c) Sec III 


\subsection{Impact of sea Level rise (SLR) on saltwater intrusion (SWI) (scenario-1)}

The results of increasing SLR by $25 \mathrm{~cm}, 50 \mathrm{~cm}$ and by $100 \mathrm{~cm}$ are shown as in Fig (15a, b and c) respectively. The Figure prevailed that, increasing SLR increases saltwater intrusion in the aquifer from North to South. Increasing SLR by $25 \mathrm{~cm}, 50 \mathrm{~cm}$ and $100 \mathrm{~cm}$ at Sec I is shown in Fig.16. The results show that SWI reaches to $78.75 \mathrm{~km}, 79.00 \mathrm{~km}$ and $79.25 \mathrm{~km}$ from shore line for Equiconcentration line 35.00 and reach $91.50 \mathrm{~km}, 91.75 \mathrm{~km}$ and $92.25 \mathrm{~km}$ for Equiconcentration line 1.00 respectively. The results also show at Sec II as shown in Fig.17, SWI reaches to $66.75 \mathrm{~km}, 67.00 \mathrm{~km}$ and $67.75 \mathrm{~km}$ from shore line for Equi-line 35.00 and reaches to $95.75 \mathrm{~km}, 96.25 \mathrm{~km}$ and $97.00 \mathrm{~km}$ for Equi-line 1.00 respectively. Figure.18 indicates the results at Sec III; the SWI reaches to $48.50 \mathrm{~km}, 48.75$ $\mathrm{km}$ and $49.00 \mathrm{~km}$ from shore line for Equi-line 35.00 and reaches to $73.00 \mathrm{~km}, 73.25 \mathrm{~km}$ and $73.75 \mathrm{~km}$ for line 1.00 respectively.

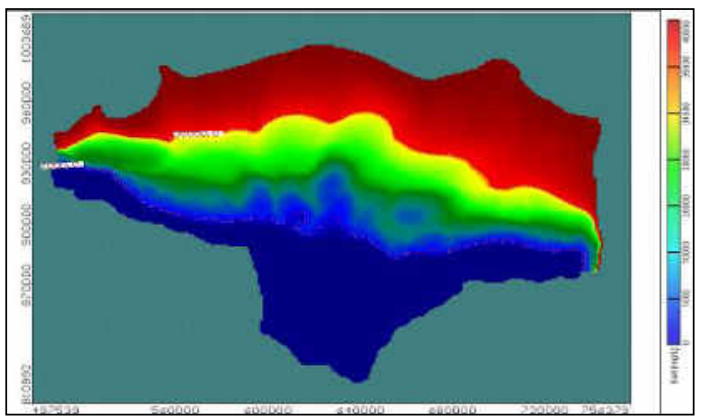

(a)

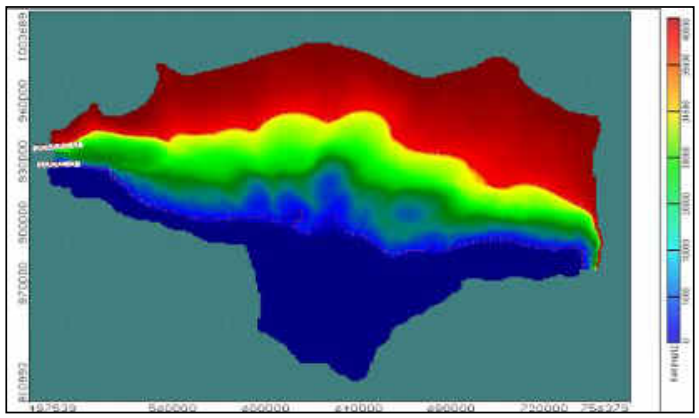

(b)

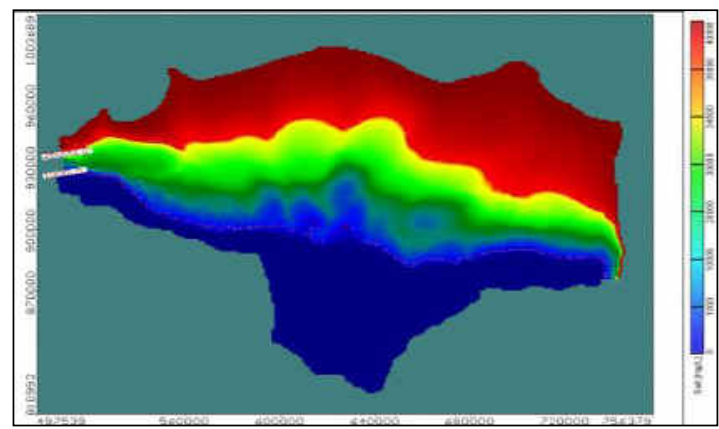

(c)

Fig. 15. Areal Distribution of TDS at Increasing SLR by (a) $25 \mathrm{~cm}$, (b) $50 \mathrm{~cm}$ and (c) $100 \mathrm{~cm}$
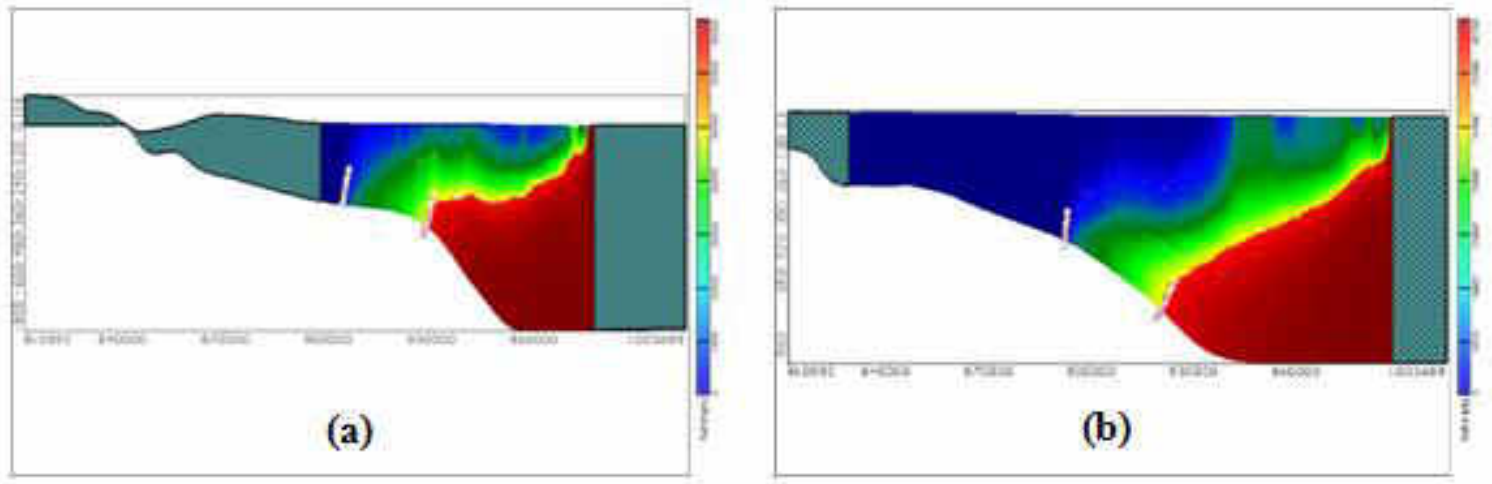


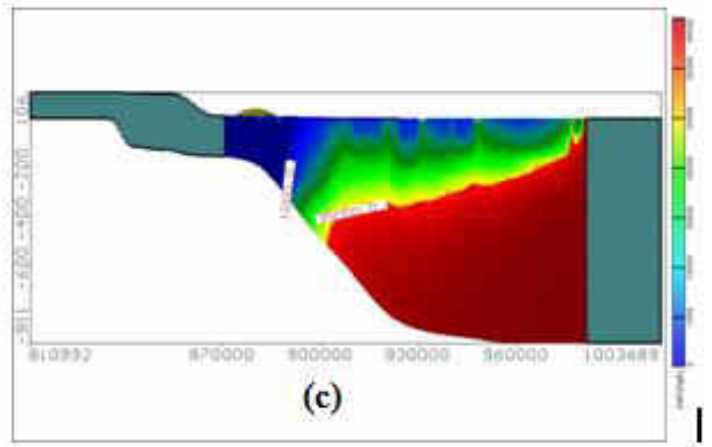

Fig. 16. Vertical Distribution of TDS in Nile delta Aquifer at SLR by (a) $25 \mathrm{~cm}$, (b) $50 \mathrm{~cm}$ and (c) $100 \mathrm{~cm}$ at Sec I

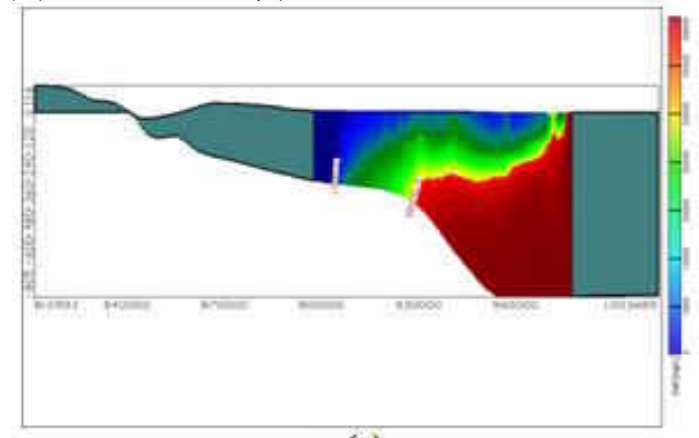

(a)

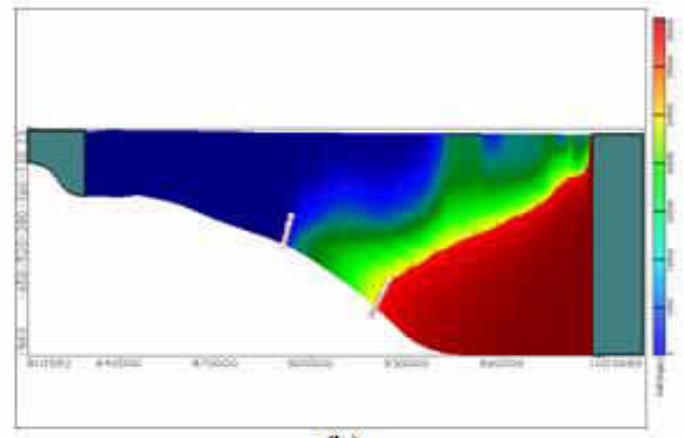

(b)

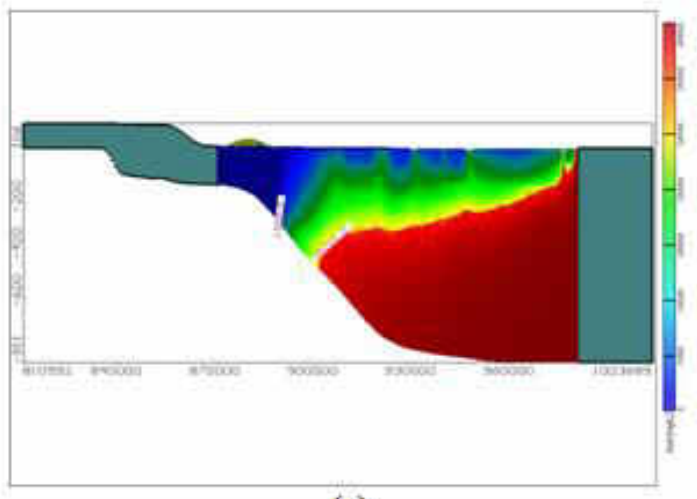

Fig. 17. Vertical Distribution of TDS in Nile delta Aquifer at SLR by (a) $25 \mathrm{~cm}$, (b) $50 \mathrm{~cm}$ and (c) $100 \mathrm{~cm}$ at Sec II
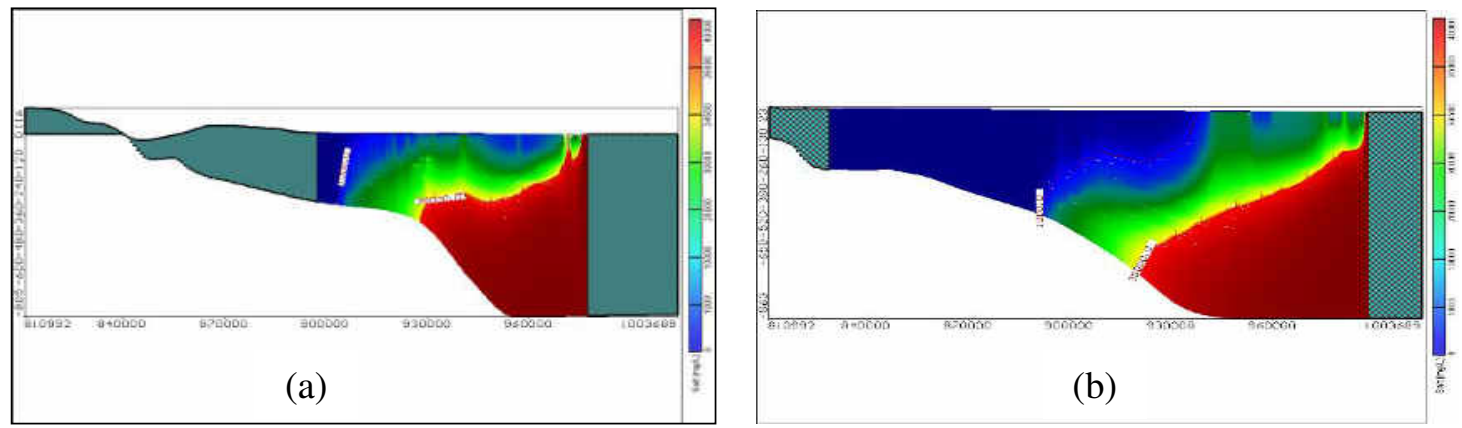


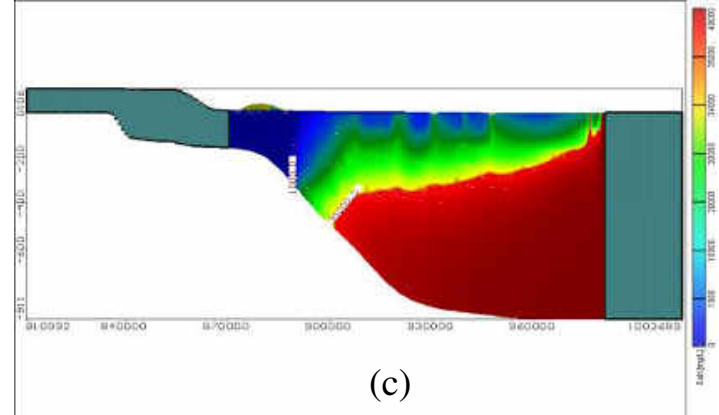

Fig. 18. Vertical Distribution of TDS in Nile delta Aquifer at SLR by (a) $25 \mathrm{~cm}$, (b) $50 \mathrm{~cm}$ and (c) $100 \mathrm{~cm}$ at $\mathbf{S e c}$ III

\subsection{Impact of surface water level change on swi (scenario-2)}

The results of decreasing surface water level by $25 \mathrm{~cm}, 50 \mathrm{~cm}$ and $100 \mathrm{~cm}$ are shown as in Fig.19-a,b and $\mathbf{c}$ respectively. The Figures show that decreasing of surface water level will increase saltwater intrusion in aquifer from shore line to South. The results at Sec I as shown in Fig.20, SWI reaches $78.50 \mathrm{~km}, 78.75 \mathrm{~km}$ and $79.00 \mathrm{~km}$ from shore line for line 35.00 and reaches $91.25 \mathrm{~km}, 91.75 \mathrm{~km}$ and $92.00 \mathrm{~km}$ for Equi-line 1.00 respectively. The results show also at Sec II as shown in Fig.21, SWI reaches $78.50 \mathrm{~km}$, $78.75 \mathrm{~km}$ and $79.00 \mathrm{~km}$ from shore line for Equi-line 35.00 and reaches $91.25 \mathrm{~km}, 91.75$ $\mathrm{km}$ and $92.00 \mathrm{~km}$ for Equi-line 1.00 respectively. The results at Sec III, as shown in Fig.22 show that SWI reaches $78.50 \mathrm{~km}, 78.75 \mathrm{~km}$ and $79.00 \mathrm{~km}$ from shore line for Equi-line 35.00 and reaches $91.25 \mathrm{~km}, 91.75 \mathrm{~km}$ and $92.00 \mathrm{~km}$ for Equi-line

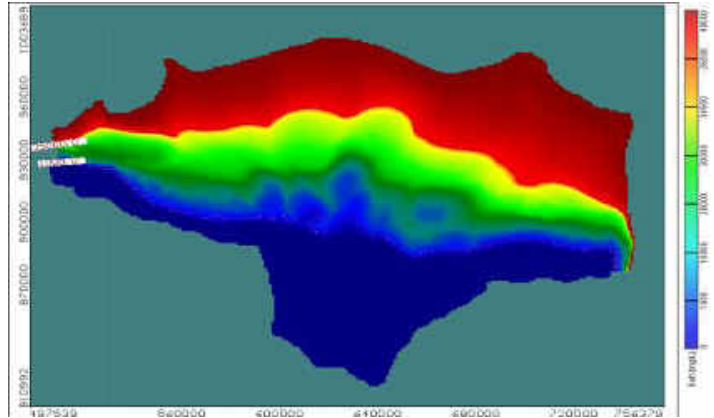

(a)

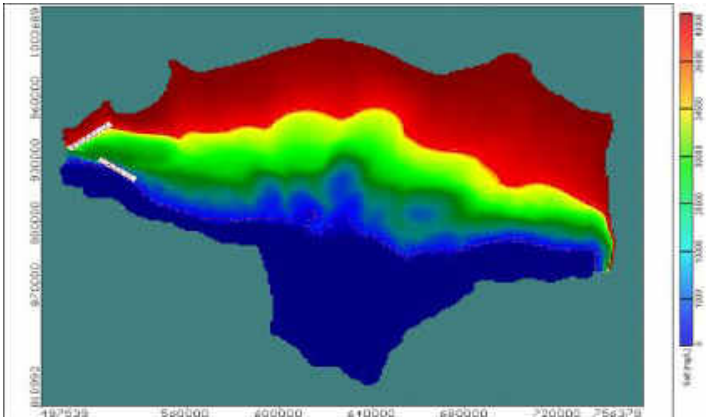

(b)

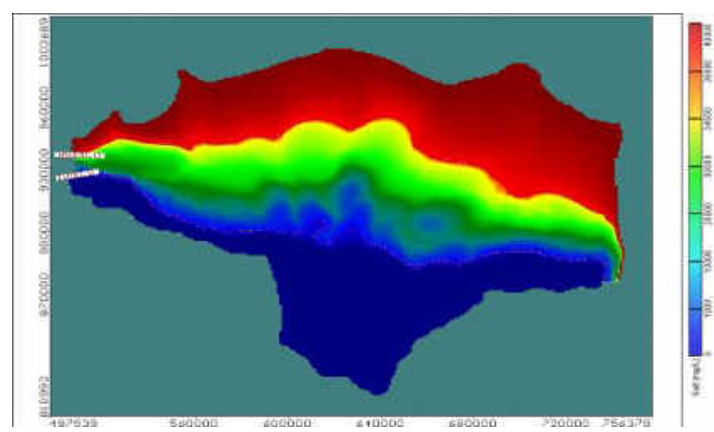

(c)

Fig. 19. Areal Distribution of TDS at Decrease Surface Water by (a) $25 \mathrm{~cm}$, (b) $50 \mathrm{~cm}$ and (c) $100 \mathrm{~cm}$ 

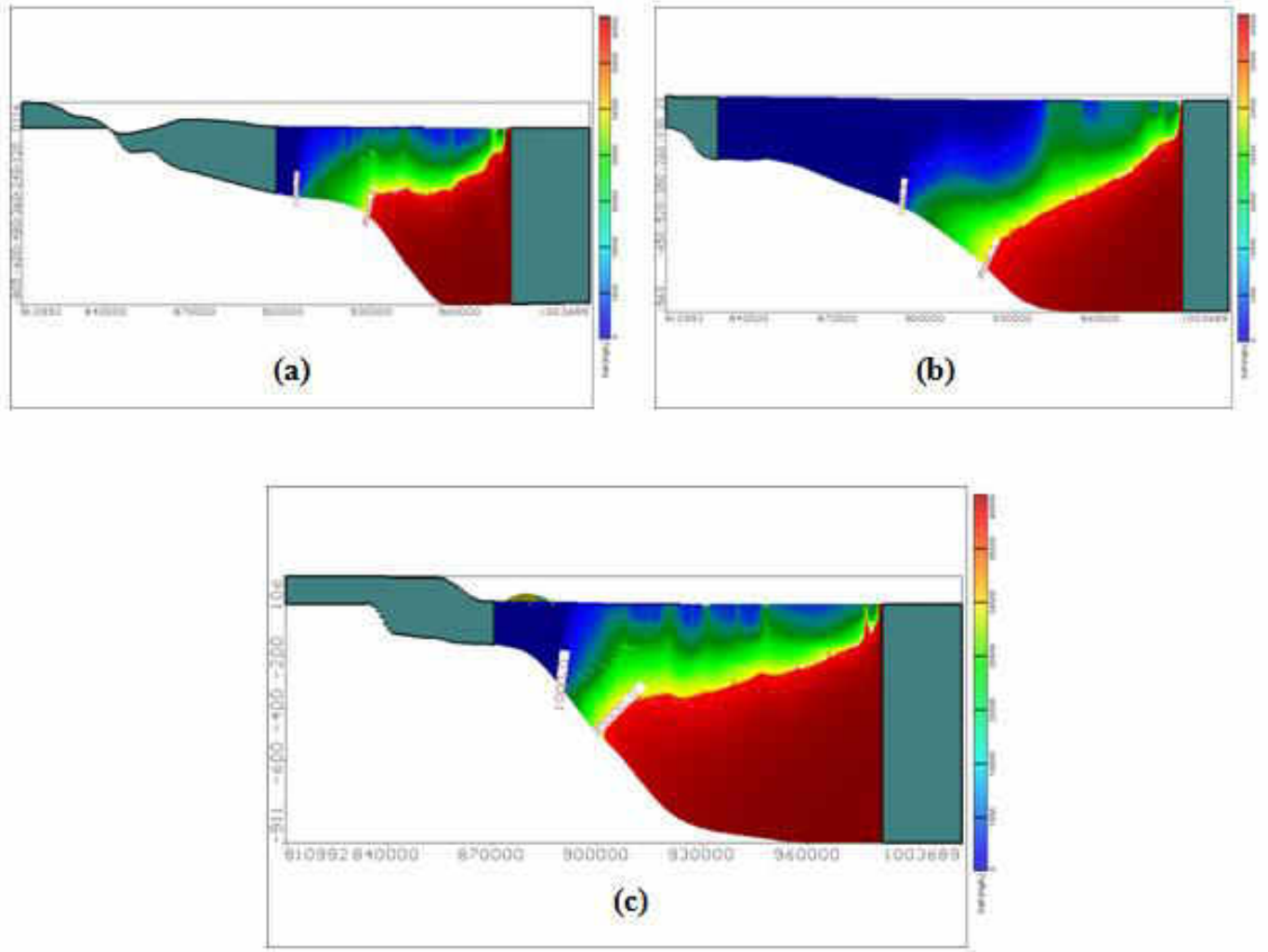

Fig. 20. Vertical Distribution of TDS in Nile delta Aquifer at Decrease Surface Water by (a) $25 \mathrm{~cm}$, (b) $50 \mathrm{~cm}$ and (c) $100 \mathrm{~cm}$ at $\mathbf{S e c ~ I ~}$
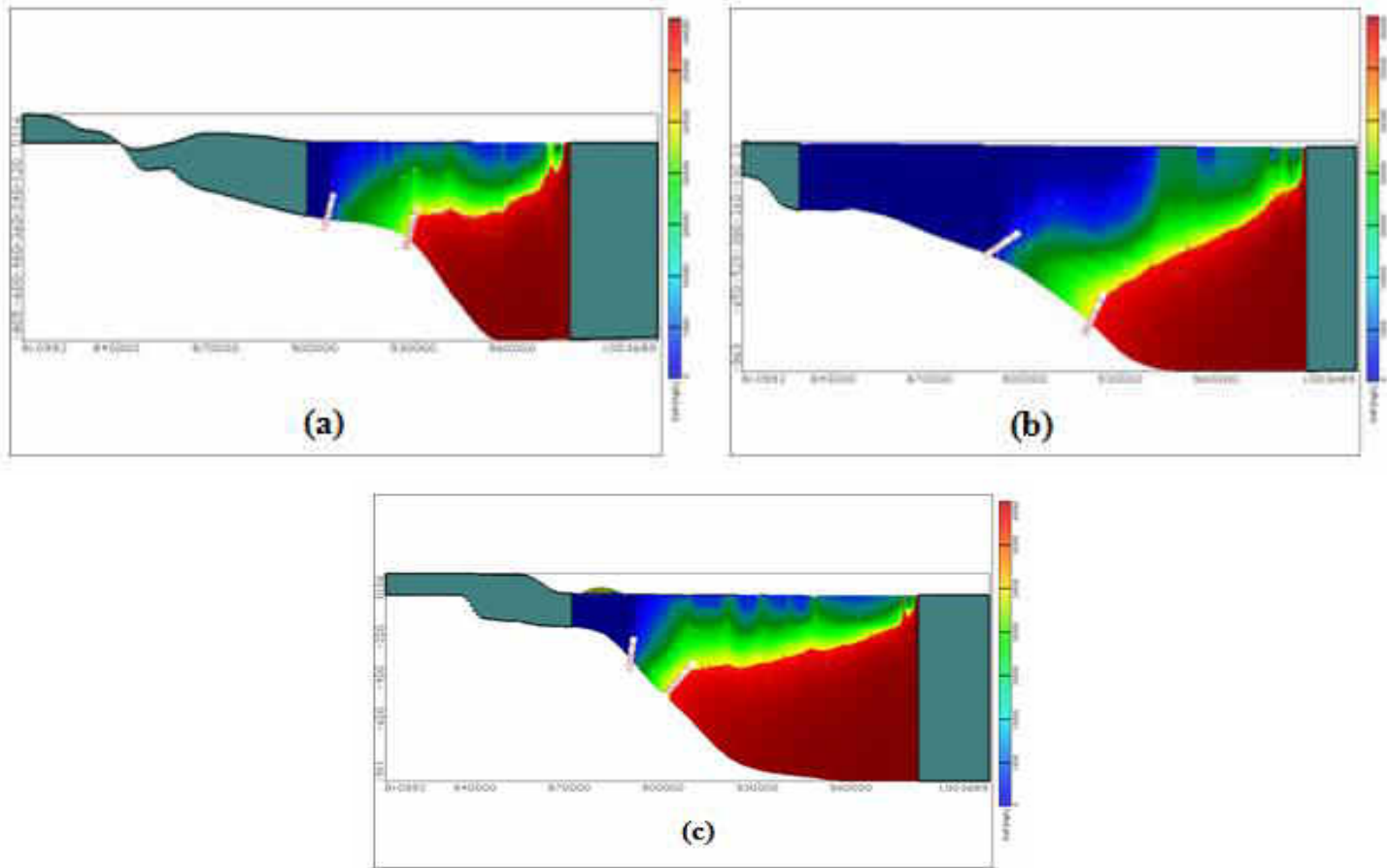

Fig. 21. Vertical Distribution of TDS in Nile delta Aquifer at Decrease Surface Water by (a) $25 \mathrm{~cm}$, (b) $50 \mathrm{~cm}$ and (c) $100 \mathrm{~cm}$ at Sec II 

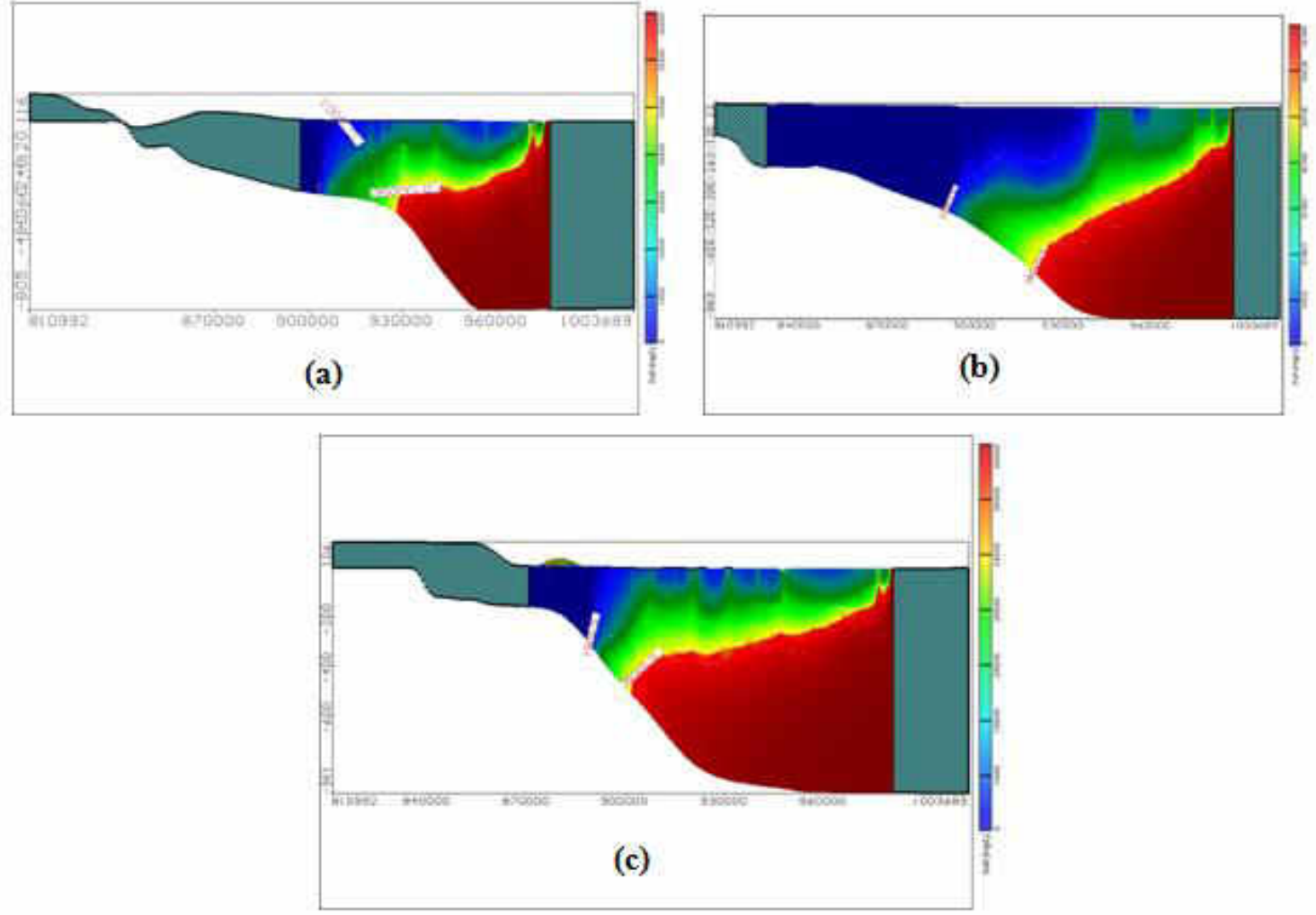

Fig. 22. Vertical Distribution of TDS in Nile delta Aquifer at Decrease Surface Water by (a) $25 \mathrm{~cm}$, (b) $50 \mathrm{~cm}$ and (c) $100 \mathrm{~cm}$ at Sec III

\subsection{Impact of increasing extraction wells change on swi (scenario-3)}

The results of increasing extraction rate by $25 \%, 50 \%$ and $100 \%$ are shown as in Fig.23$\mathbf{a}, \mathbf{b}$ and $\mathbf{c}$. The Figures indicate that the increase of extraction rate increases SWI in aquifer from shore line to South. Increasing extraction rates by $25 \%, 50 \%$ and $100 \%$ on SWI at Sec I, as shown in Fig.24 causes the SWI reaches $48.25 \mathrm{~km}, 47.50 \mathrm{~km}$ and $45.50 \mathrm{~km}$ from shore line for Equi-line 35.00 and to $73.00 \mathrm{~km}, 74.00 \mathrm{~km}$ and $79.50 \mathrm{~km}$ for Equi-line 1.00 respectively .The results show also at Sec II as shown in Fig.25, the SWI reaches $63.75 \mathrm{~km}$, $66.50 \mathrm{~km}$ and $65.75 \mathrm{~km}$ from shore line for Equi-line 35.00 and reaches $98.25 \mathrm{~km}, 101.25 \mathrm{~km}$ and $107.75 \mathrm{~km}$ for Equi-line 1.00 respectively. Again the results at Sec III as shown in Fig.26 show that the SWI length reaches $80.50 \mathrm{~km}, 81.50 \mathrm{~km}$ and $82.00 \mathrm{~km}$ from shore line for Equiline 35.00 and reaches to $91.00 \mathrm{~km}, 91.50 \mathrm{~km}$ and $91.75 \mathrm{~km}$ for Equi-line 1.00 respectively.

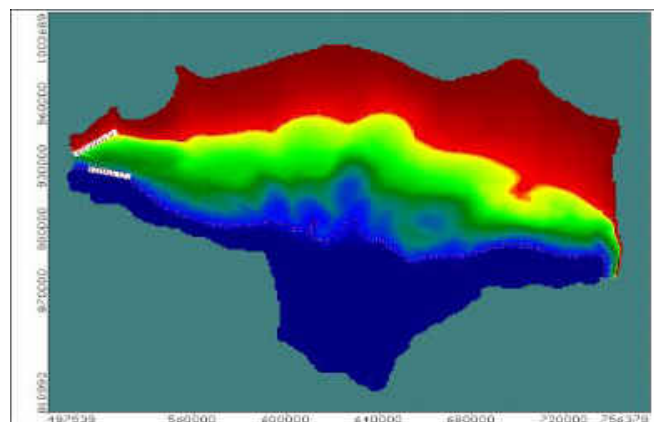

(a)

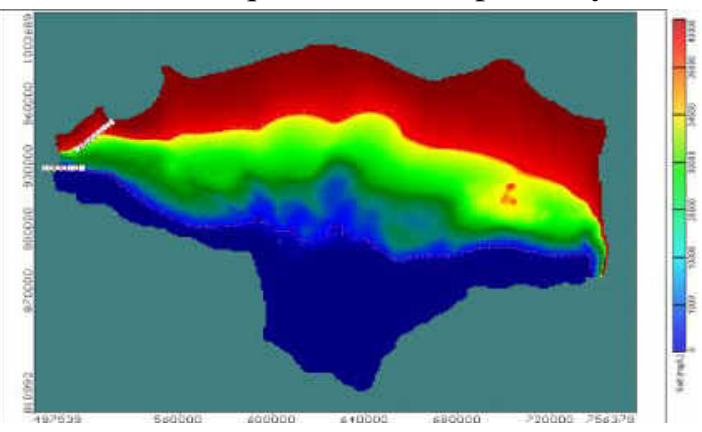

(b) 


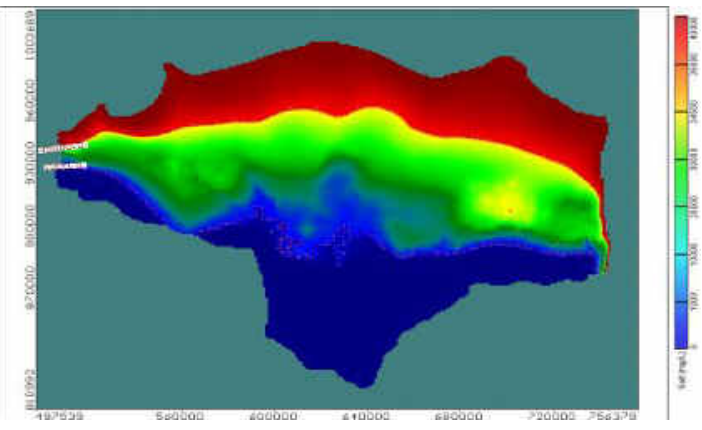

(c)

Fig. 23. Areal Distribution of TDS Increasing Extraction Wells by (a) $25 \%$, (b) $50 \%$ and (c) $100 \%$.
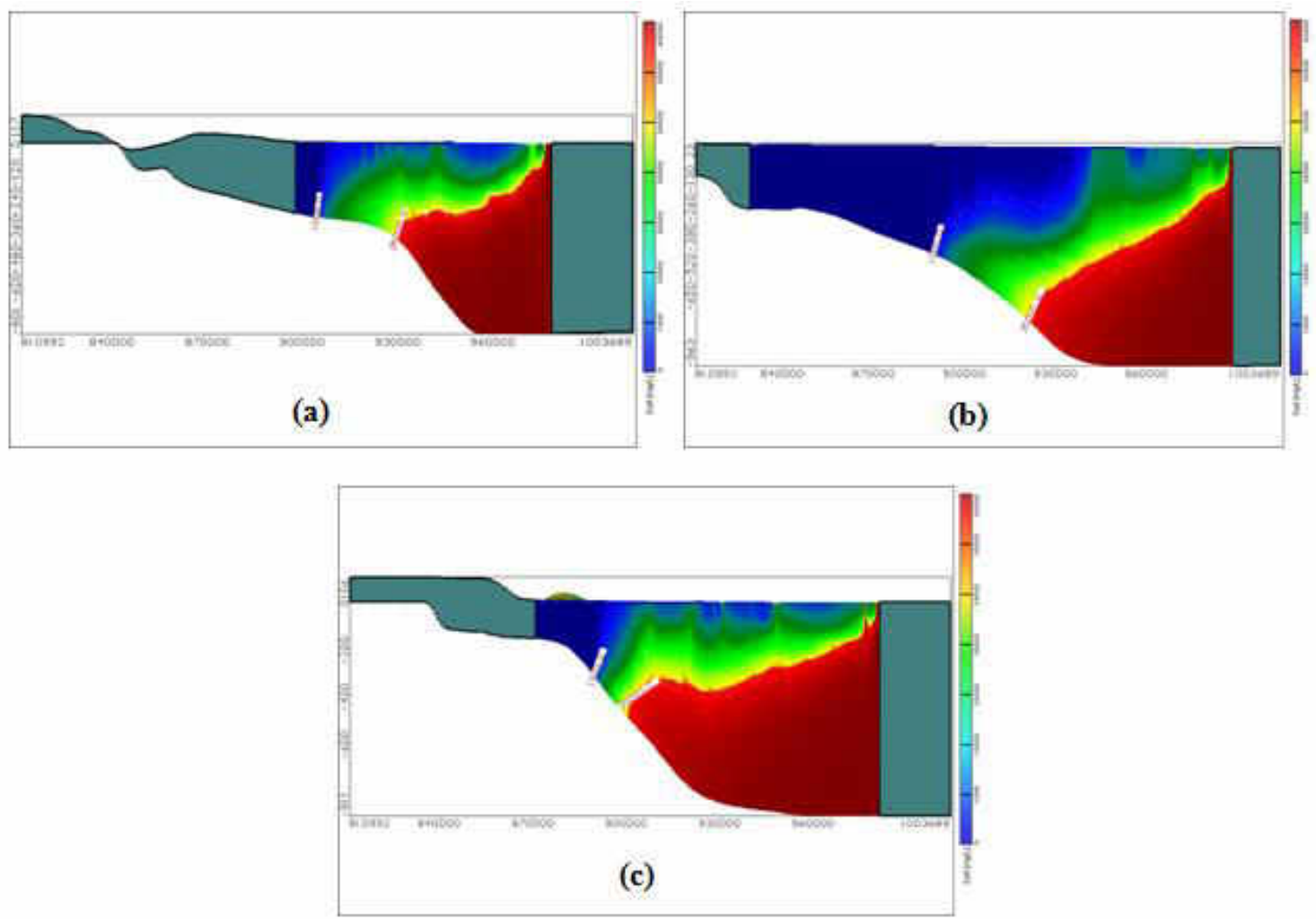

Fig. 24. Vertical Distribution of TDS in Nile delta Aquifer for Increasing Extraction Wells by (a) $25 \%$, (b) $50 \%$ and (c) $100 \%$ at Sec I 

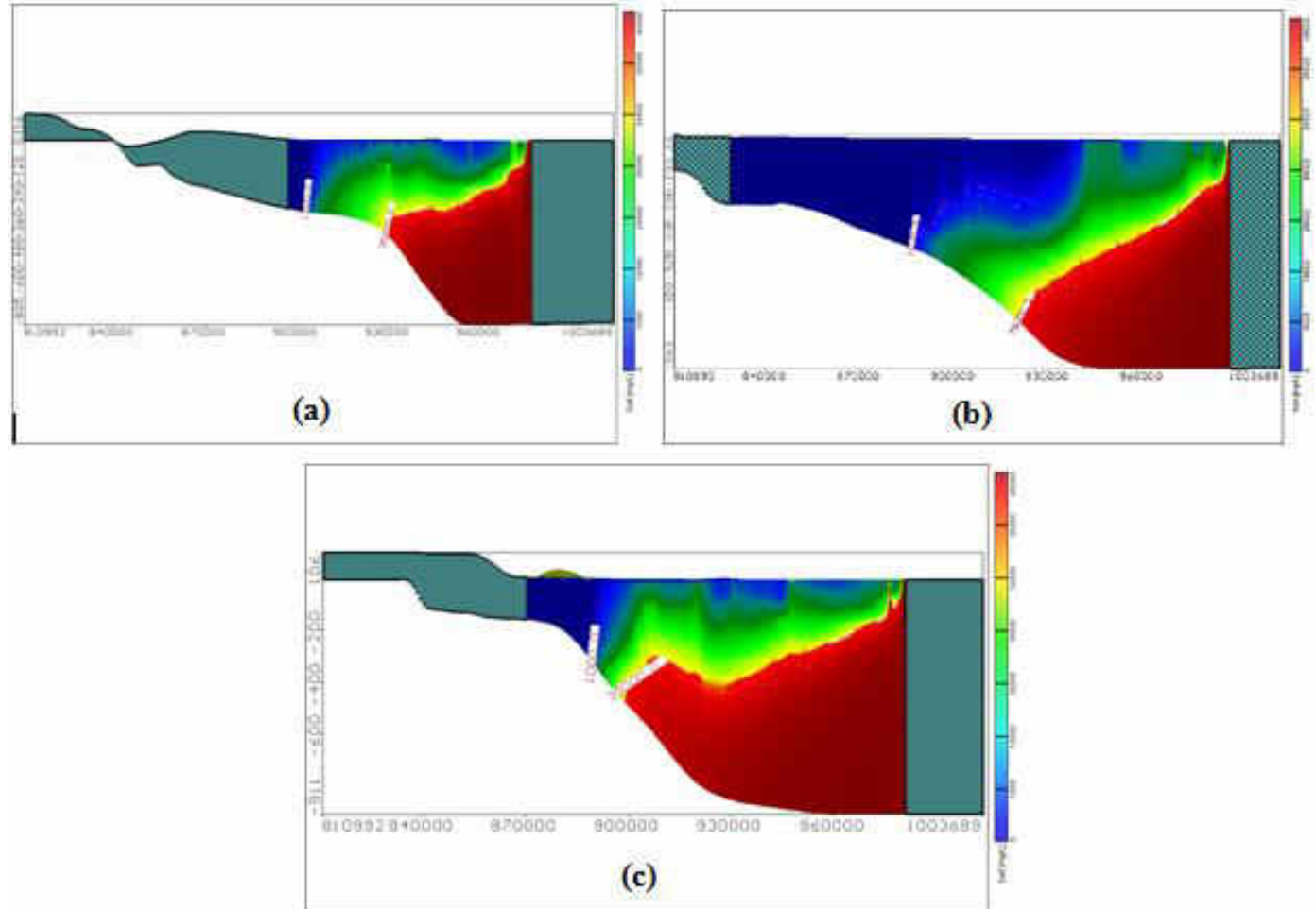

Fig. 25. Vertical Distribution of TDS in Nile delta Aquifer for Increasing Extraction Wells by (a) $25 \%$, (b) $50 \%$ and (c) $100 \%$ at Sec II
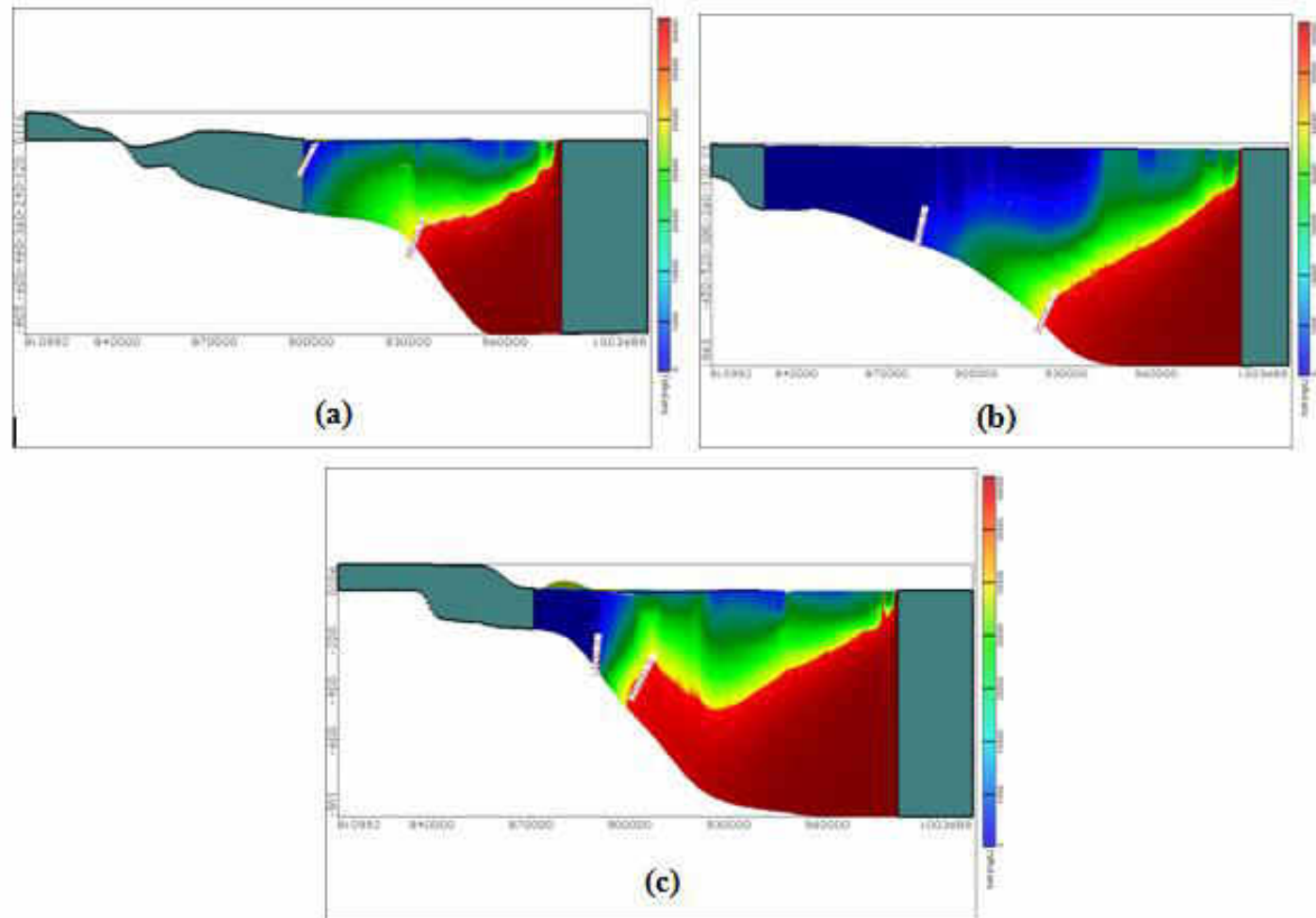

Fig. 26. Vertical Distribution of TDS in Nile delta Aquifer for Increasing Extraction Wells by (a) $25 \%$, (b) $50 \%$ and (c) $100 \%$ at Sec III 


\subsection{Impact of three combination scenario change on SWI (scenario-4)}

The results of increasing SLR by $25 \mathrm{~cm}, 50 \mathrm{~cm}$ and $100 \mathrm{~cm}$, decreasing surface water system by $25 \mathrm{~cm}, 50 \mathrm{~cm}$ and $100 \mathrm{~cm}$ and increasing extraction rates by $25 \% 50 \%$ and 100\% are shown as in Fig.27-a,b and $\mathbf{c}$ show the increase of SWI in aquifer from shore line to South. The results at Sec I as shown in Fig.28 the SWI reaches $48.75 \mathrm{~km}, 48.50 \mathrm{~km}$ and $47.75 \mathrm{~km}$ from shore line for Equi-line 35.00 and reaches $73.50 \mathrm{~km}, 76.25 \mathrm{~km}$ and $79.50 \mathrm{~km}$ for Equi-line 1.00 respectively. Also The results at Sec II as shown in Fig.29 concluded that SWI reaches $66.75 \mathrm{~km}, 67.25 \mathrm{~km}$ and $67.50 \mathrm{~km}$ from shore line for Equiline 35.00 and reaches $99.25 \mathrm{~km}, 103.25 \mathrm{~km}$ and $110.00 \mathrm{~km}$ for Equi-line 1.00 respectively. The Combination of three Scenarios results that, at Sec III as shown in Fig.30 the SWI reaches $80.50 \mathrm{~km}, 82.00 \mathrm{~km}$ and $83.00 \mathrm{~km}$ from shore line for line 35.00 and reaches $91.50 \mathrm{~km}, 91.75 \mathrm{~km}$ and $92.75 \mathrm{~km}$ for Equi-line 1.00 respectively.

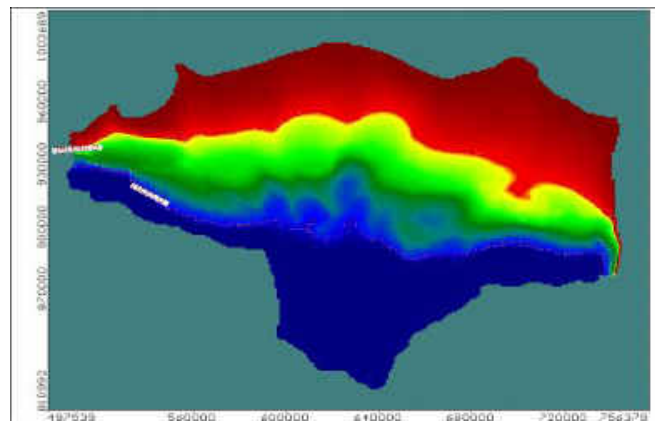

(a)

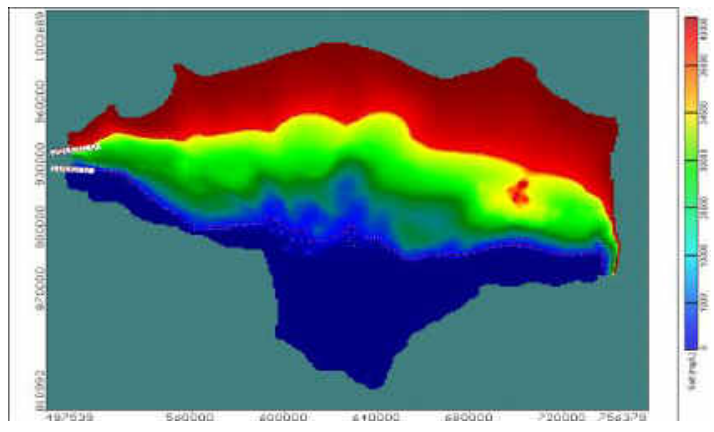

(b

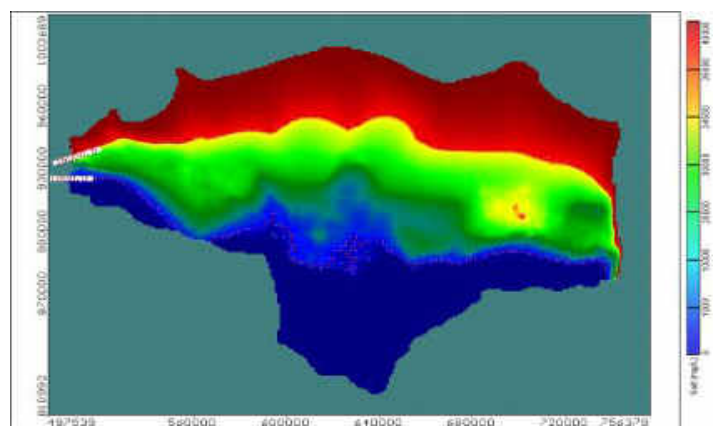

(c)

Fig. 27. Areal Distribution of TDS for Combination of Three Scenarios Change by (a) $25 \%$, (b) $50 \%$ and (c) $100 \%$.
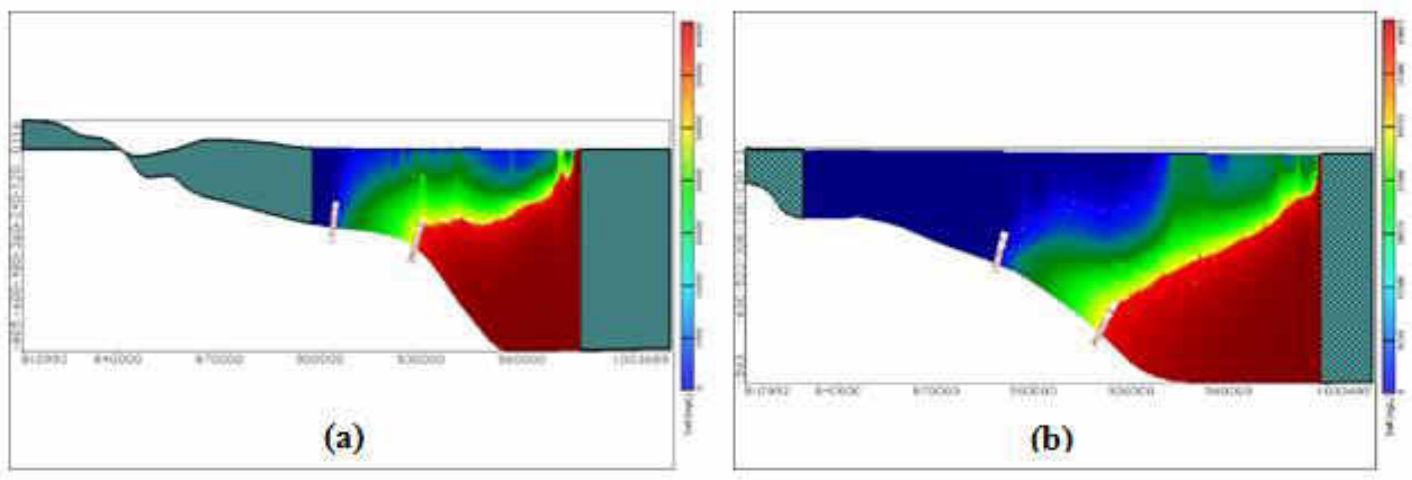


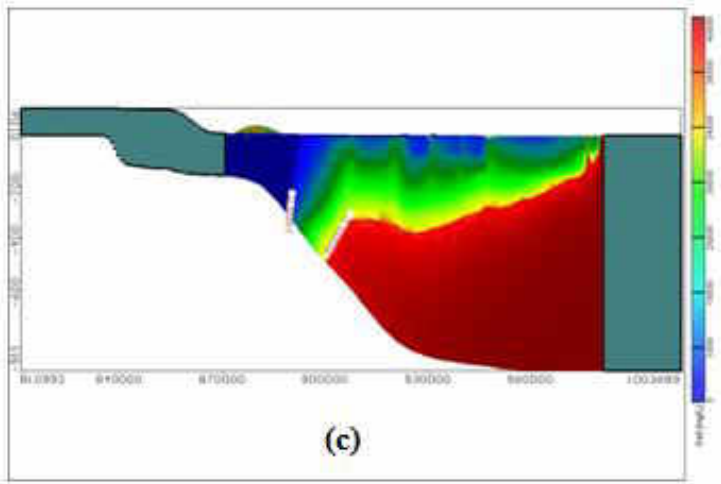

Fig. 28. Vertical Distribution of TDS in Nile delta Aquifer for Combination of Three Scenarios Change by (a) $25 \%$, (b) $50 \%$ and (c) $100 \%$ at Sec I
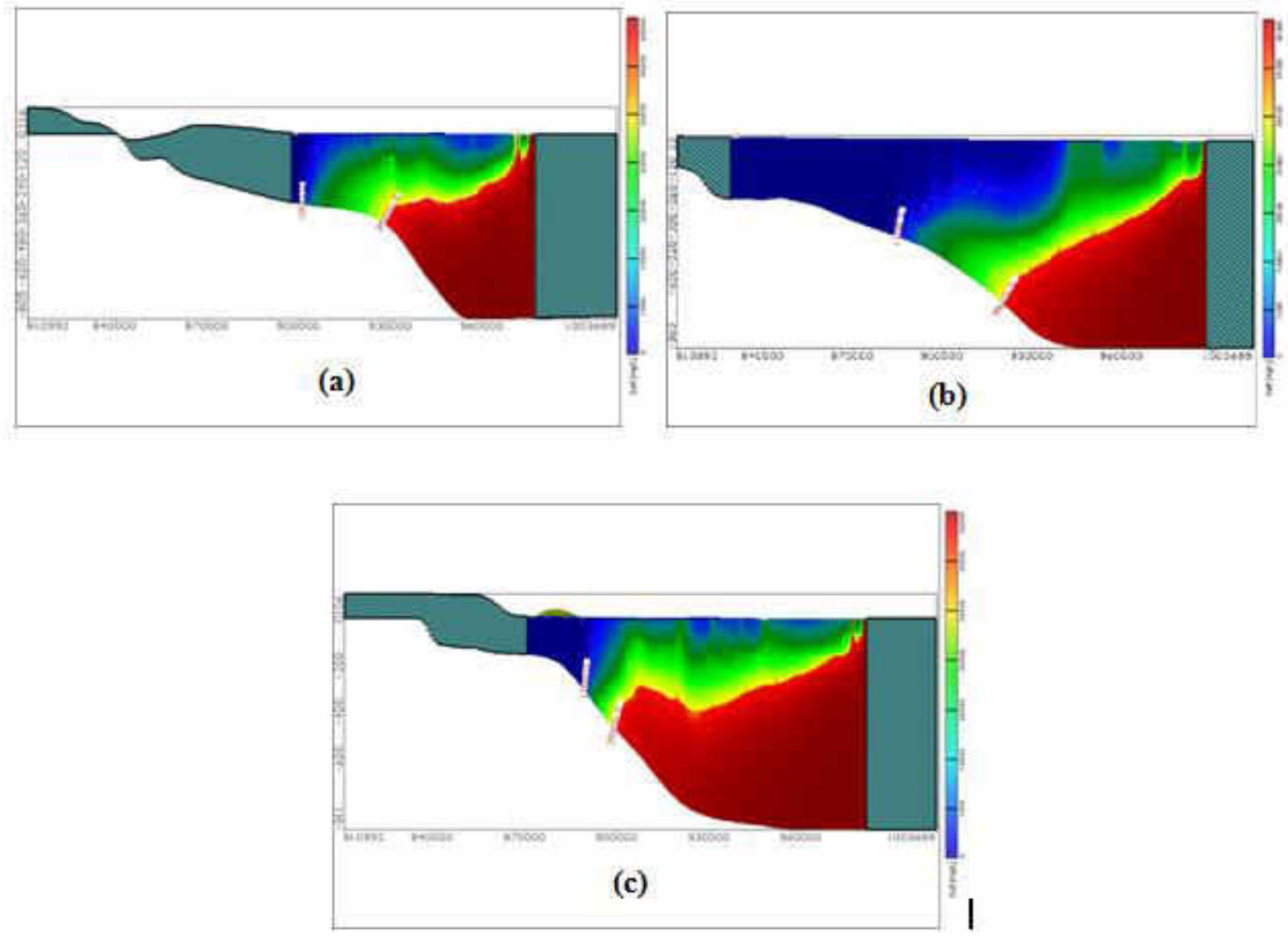

Fig. 29. Vertical Distribution of TDS in Nile delta Aquifer for Combination of Three Scenarios Change by (a) $25 \%$, (b) $50 \%$ and (c) $100 \%$ at Sec II 

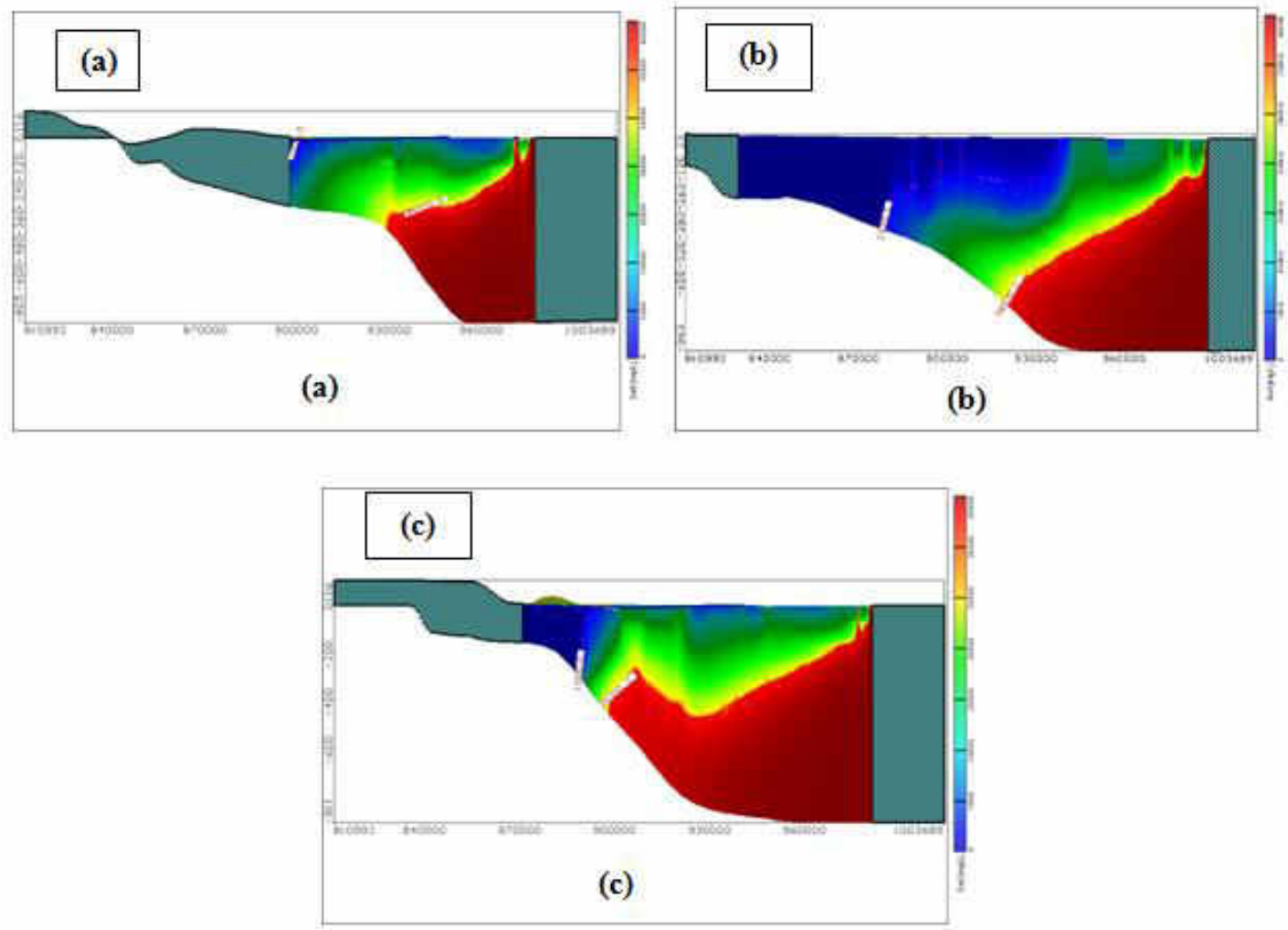

Fig. 30. Vertical Distribution of TDS in Nile delta Aquifer for Combination of Three Scenarios Change by (a) $25 \%$, (b) $50 \%$ and (c) $100 \%$ at Sec III

\section{Conclusions}

The main objective of this research was to study the effect of SLR, decreasing surface water level, increasing extraction and combination of this scenarios on saltwater intrusion in Nile delta aquifer. The results of show that:

1. Increasing SLR by $25 \mathrm{~cm}, 50 \mathrm{~cm}$ and $100 \mathrm{~cm}$ (Scenario-1) leads to an increase in SWI to reach 73, 73.25 and $73.75 \mathrm{~km}$ in the West, at the Middle the SWI reach $95.75 \mathrm{~km}, 96.25 \mathrm{~km}$ and $97 \mathrm{~km}$, also at the East the SWI reach 91.50, 91.75 and $92.25 \mathrm{~km}$ respectively for Equi-line 1.00 .

2. Decreasing surface water level by $25 \mathrm{~cm}, 50 \mathrm{~cm}$ and $100 \mathrm{~cm}$ (Scenario-2) increases SWI to reach $73.25 \mathrm{~km}, 73.75 \mathrm{~km}$ and $74 \mathrm{~km}$ at the West, at the Middle the SWI reach $96 \mathrm{~km}, 96.50 \mathrm{~km}$ and $97.50 \mathrm{~km}$, also at the East the SWI reach $91.25 \mathrm{~km}, 91.75 \mathrm{~km}$ and $92 \mathrm{~km}$ for Equi-line 1.00 .

3. Increasing extraction rates by $25 \%, 50 \%$ and $100 \%$ (Scenario-3) leads to an increase in SWI to reach $73 \mathrm{~km}, 74 \mathrm{~km}$ and $79.50 \mathrm{~km}$ at the West, at the Middle the SWI reach $98.25 \mathrm{~km}, 101.25 \mathrm{~km}$ and $107.75 \mathrm{~km}$, also at the East the SWI reaches $91 \mathrm{~km}, 91.50 \mathrm{~km}$ and $91.75 \mathrm{~km}$ for Equi-line1.00.

4. The most effective scenarios is the combination of increasing extraction rates, increasing SLR and decreasing surface water system (Scenario-4) causes the SWI 
intrusion reach to $73.50,76.25$ and $79.50 \mathrm{~km}$ at the West, at the Middle the SWI reach $99.25 \mathrm{~km}, 103.25 \mathrm{~km}$ and $110 \mathrm{~km}$, also at the East the SWI reach $91.50 \mathrm{~km}$, $91.75 \mathrm{~km}$ and $92.75 \mathrm{~km}$ for Equi-line 1.00. Combinations of three Scenarios have strong effect on SWI.

\section{Recommendations}

It could be recommended to study different scenarios to control of saltwater intrusion considering climatic change in Nile delta aquifer to protect groundwater.

\section{REFERENCES}

[1] Abd-Elhamid .H.F and Javadi A.A, (2008). "An Investigation into Control of Saltwater Intrusion Considering the Effects of Climate Change and Sea Level Rise". Proceeding of $20^{\text {th }}$ SWIM, June 23-27, 2008, Naples, Florida, USA

[2] Abd-Elhamid .H.F and Javadi A.A, (2011). "A density-Dependant Finite Element Model for Analysis of Saltwater Intrusion in Coastal Aquifers". Journal of Hydrology, Vol (401), PP 259-271.

[3] Agrawala Shardul, Annett Moehner, Mohamed El Raey, Declan Conway, Maarten van Aalst, Marca Hagenstad and Joel Smith, (2004). "Development and Climate Change in Egypt: Focus on Coastal resources and the Nile", Environment Policy Committee, Working Party on Global and Structural Policies and Working Party on Development Cooperation and Environment, Organization for Economic Co-operation and Development (OECD).

[4] Alexander Vandenbohede, (2003-2004). "Solute Transport in Heterogeneous Aquifers Parameter Identification and its use in Groundwater Pollution and Saltwater Intrusion Problems". Faculty Wetenschappen, Vakgroep Geology en Bodemkunde, Academic year 2003-2004.University Gent, Text book.

[5] Barnett B, Townley LR, Post V, Evans RE, Hunt RJ, Peeters L, Richardson S, Werner AD, Knapton A and Boronkay A., (2012). "Australian Groundwater Modeling Guidelines". Waterlines Report Series No. 82 .National Water Commission, Canberra.

[6] Bear, J., Cheng, A. H., Sorek, S., Quazar, D. and Herrera, I. (1999). "Seawater Intrusion in Coastal Aquifers, Concepts, Methods and Practices", Kluwer Academic publisher, Dordrecht, The Netherlands. ISBN 0-7923-5573-3.

[7] Bahr, R., (1995),"'Groundwater Management and Saltwater Intrusion in Nile Delta Aquifer “

Berlin TU, Germany.

[8] Ciaran H., (2002). "The effect of Basement on Heterogeneity on Saltwater Wedge A physical and Numerical Modelling Approach". The University of Western Australasia. Text Book.

[9] Domenico, P.A. and Schwartz, F.W., (1998). "Physical and chemical hydrogeology". Second Edition. John Wiley \& Sons, New York.

[10] El-Arabi M., (2007)."Environmental Impact of New Settlements in Groundwater in a Region in the Nile Delta". M.Sc. Thesis, Fac. of Eng., Zagazig University.

[11] El Raey, Mohammed, (2009)." Vulnerability Assessment of the Coastal Zone of the Nile Delta, Egypt, to the Impacts of Sea Level Rise”. Ocean and Coastal Management, Vol 37, No 1, 29-40.

[12] Farid M.S., (1980).”Nile delta groundwater study”. M.Sc. Thesis, Fac. of Eng., Cairo University.

[13]Fang, H. Y, (1997).” Introduction to Environment Geo-technology “. (pp. 448-450).USA: CRC Press LLC.

[14] Freeze, R. A. and Cherry, J. A, (1979).” Groundwater “. (PP. 375-379).USA: Prentice Hall, Inc. 
[15]Hefny, K.H., (1980). " Groundwater in the Nile Valley, Ministry of Irrigation". Water Research Center. Groundwater Research inst. (In Arabic). pp. 1-120.

[16]Hegerl, G.C., (2007). "Historical Overview of Climate Change Science", Cambridge University Press, Cambridge, United Kingdom and New York, NY, USA.

[17] Intergovernmental Panel on Climate Change (IPCC), (2001). "Third Assessment Report of the Intergovernmental Panel on Climate Change", the Pitt Building, Trumpington Street, Cambridge, United Kingdom.

[18] IPCC, (2007). "An Assessment of the Intergovernmental Panel on Climate Change", Adopted section by section at IPCC Plenary XXVII (Valencia, Spain, 12-17 November 2007), Represents the Formally Agreed Statement of the IPCC Concerning key Findings and Uncertainties Contained in the Working Group Contributions to the Fourth Assessment Report.

[19] Javadi A.A, Abd-Elhamid, H.F and Sherif, M.M., (2013). "Numerical Modelling and Control of Seawater Intrusion in Coastal Aquifers", Proceedings of the $18^{\text {th }}$ International Conference on Soil Mechanics and Geotechnical Engineering, Paris.

[20] Leaven, M.T.,(1991)."Hydrological Study of the Nile Delta and Adjacent Desert Areas, Egypt, with Emphasis on Hydrochemistry and Isotope Hydrology“, M.Sc thesis, Free University, Amsterdam. Also Published by RIGW/IWACO as Technical Note TN 77.01300-91-01.

[21] Ministry of Water Resources and Irrigation (MWRI), (2013). "Proposed Climate Change Adaptation Strategy for the Ministry of Water Resources and Irrigation in Egypt", Ministry of Water Resources and Irrigation.

[22] Morsy, W. S., (2009). "Environmental management to groundwater resources for Nile Delta region", $\mathrm{PhD}$ thesis, Faculty of Engineering, Cairo University, Egypt.

[23] NGCLC, National Groundwater \& Contaminated Land Centre, (2001)." Guide to Good Practice for the Development of Conceptual Models and the Selection and Application of Mathematical Models of Contaminant Transport Processes in the Subsurface", NGCLC report NC/99/38/2.

[24] Peter Callander, (2011). "New Zealand Guidelines for the Monitoring and Management of Sea Water Intrusion Risks on Groundwater", Envirolink Project 420-NRLC50, , text book.

[25] Prickett T .A, (1975). "Modeling Techniques for Groundwater Evaluation" , Advances in Hydroscience, Vol (10), PP 1-143.

[26] Randolf Rausch, (2010). "Groundwater Modeling, an Introduction to Groundwater Flow and Solute Transport Modeling with Application". Technische Universitat Darmstadt. Berlin, Text Book.

[27] RIGW, (1980). "Project of Safe Yield Study for Groundwater Aquifers in the Nile delta and Upper Egypt “, Part 1. (In Arabic).Ministry of Irrigation, Academy of Science Research and Technology, and Organization of Atomic Energy .Egypt.

[28] RIGW, (1992). "Research Institute for Groundwater, Hydrogeological Map of Nile Delta", Scale 1: 500,000, 1st Edn., Nile Delta.

[29]RIGW, (2002). "Nile Delta Groundwater Modeling Report", Research Inst. for Groundwater, Kanater El-Khairia, Egypt, 2002.

[30] Sallouma, M.K.M.; (1983), "Hydrogeological and Hydrochemical studies east of Nile Delta, Egypt “. Ph.D. Thesis, Fac. Sci. Ain Shams Univ., 166 P.

[31] Shahien, M., (1987). "Hydrology of the Nile Basin Development in Water Science", 21, Amsterdam Netherlands. Elsevier Science publishers, B.V.575 P.

[32] Sherif, M. M., Singh, V. P., and Amer, A. M. (1988). "A two Dimensional Finite Element Model for Dispersion (2D-FED) in Coastal Aquifers". J. Hydrol. 103, 11-36.

[33] Sherif, M.M. and Muhammad F. Al-Rashed (2001). "Vertical and Horizontal Simulation of Seawater Intrusion in the Nile Delta Aquifer First International Conference on Saltwater 
Intrusion and Coastal Aquifers.Monitoring, Modeling, and Management”, Essaouira, Morocco, April 23.25.

[34] Sherif, M.M., Ahmed Sefelnasr and Akbar Javadi, (2012). "Incorporating the concept of Equivalent Freshwater Head in Successive Horizontal Simulations of Seawater Intrusion in the Nile Delta aquifer, Egypt". Journal of Hydrology 464-465, 186-198.

[35] Simonett, Otto (2002)."Nile Delta: Potential Impact of Sea Level Rise", UNEP/GRIDArendal,http://maps.grida.no/go/graphic/nile_delta_potential_impact_of_sea_ level_rise (accessed June 4, 2009).

[36] SWS (Schlumberger Water Services), (2010). "MODFLOW User's Manual. 460 Phillip Street - Suite 101 Waterloo, Ontario, CANADA, N2L 5J2.

[37] Todd, D. K. (1974). "Salwater Intrusion and its Control", Water Technology/ Resources.

[38] Journal of American Water Works Association, Vol (66), No. (3),PP 180-187.

[39] Tanapol Sriapai, Chaowarin Walsri, Decho Phueakphum, and Kittitep Fuenkajorn (2012). "Physical Model Simulations of Sea-water Intrusion in Unconfined Aquifer". Songklanakarin J. Sci. Technol Vol (34), No. (6), PP 679-687.

[40]Zaghloul M.G., (1958). "Flow Distribution through Groundwater Aquifer of the Nile Delta", M.Sc. thesis, Faculty of Engineering, Alex University.

[41]Zheng, C., and Bennett, G.D., (1995). " Applied Contaminant Transport Modeling, Theory and Practice", Van Nostrand Reinhold, 440 p. 
JES, Assiut University, Faculty of Engineering, Vol. 42, No. 4, July 2014, pp. $931-955$

"دراسة تأثثر التغيرات المناخية لتداخل المياه المالحة علي خزان الدلتا بمصر"

الملخص العربى

تعتبر ظاهرة تداخل المياه المالحة داخل الخزانات الجوفية الساحلية من أخطر الظواهر الهر الطبيعية التي تهدد

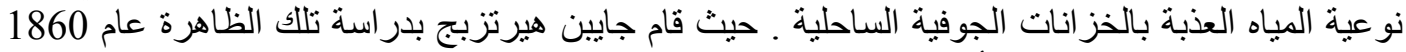

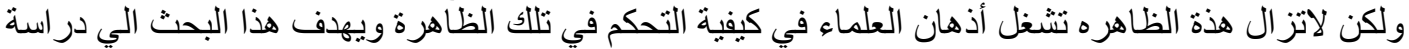

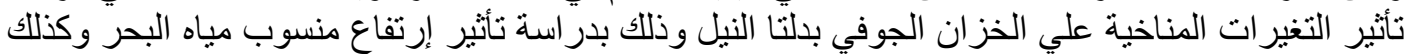

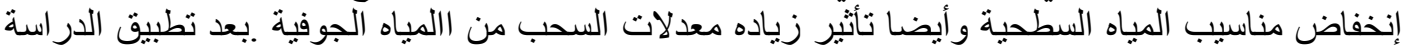

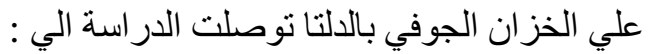

1- من خلال تطبيق النموذج علي خزان الدلتا إتضح أن التداخل يصل الي 90.75 كم في شرق الدلتا

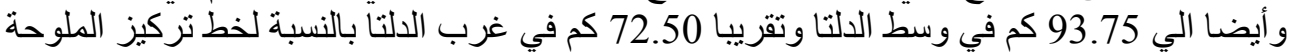
يصل الي 1000 جزء في المليون.

2- إرتفاع منسوب مياه البحر(سيناريو 1) بمقدار 25 سم و50 سم و500 سم سوف يؤدي الي زيادة تداخل المياه المالحة داخل الخزان لتصل التصل الي

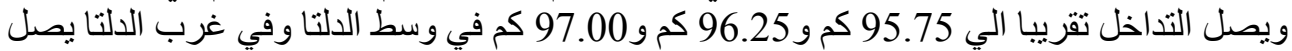
التداخل تقريبا الي 73.00 كم و 73.25 كم و73.50 كم في شرق الدالتا علي الترتيب.

3- إنخفاض منسوب مياه السطحية (سيناريو 2) بمقدار 25 سم و50 سم و100 سم سوف يؤدي الي

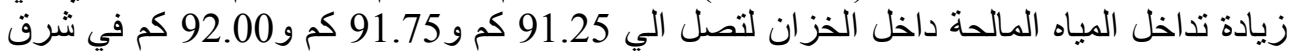
الدلتاويصل التداخل تقريبا الي

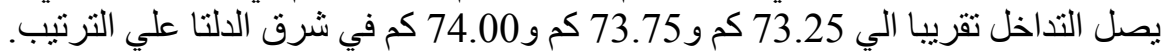
4- زيادة معدل السحب من المياه الجوفية (سيناريو 3) بمقدار 25 \%و 50 \% \% و الي زيادة تداخل المياه المالحة داخل الخزان لتئل التصل الي شرق الدلتا ويصل التداخل تقريبا الي

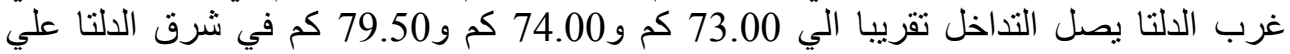
الترنيب.

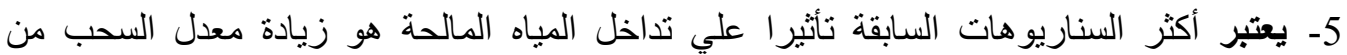

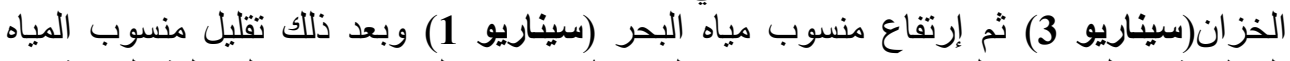

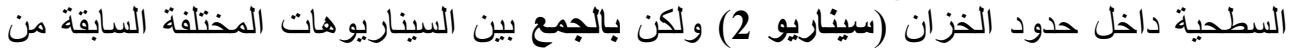

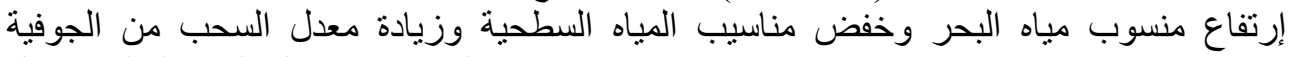

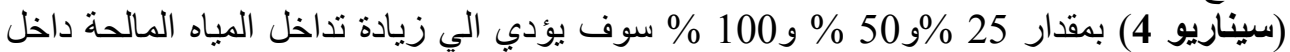

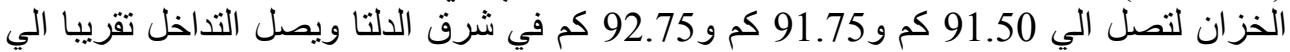

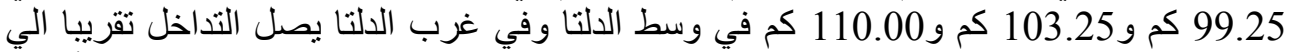
73.50 كم و77.25 كم و79.50 كم في شرق الدلتا علي الترتيب ويعتبر هذا السيناريو من أخطر السناريوهات التي ستهدد نوعية المياه العذبة بالخز ان الجوفي بالدئا. 